Atmos. Chem. Phys., 13, 9675-9693, 2013

www.atmos-chem-phys.net/13/9675/2013/

doi:10.5194/acp-13-9675-2013

(c) Author(s) 2013. CC Attribution 3.0 License.

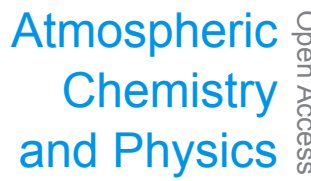

\title{
Satellite observation of lowermost tropospheric ozone by multispectral synergism of IASI thermal infrared and GOME-2 ultraviolet measurements over Europe
}

\author{
J. Cuesta ${ }^{1}$, M. Eremenko ${ }^{1}$, X. Liu ${ }^{2}$, G. Dufour ${ }^{1}$, Z. Cai ${ }^{3}$, M. Höpfner ${ }^{4}$, T. von Clarmann ${ }^{4}$, P. Sellitto ${ }^{1}$, G. Foret ${ }^{1}$, \\ B. Gaubert ${ }^{1}$, M. Beekmann ${ }^{1}$, J. Orphal ${ }^{4}$, K. Chance ${ }^{2}$, R. Spurr ${ }^{5,2}$, and J.-M. Flaud ${ }^{1}$ \\ ${ }^{1}$ Laboratoire Interuniversitaire des Systèmes Atmosphériques (LISA), CNRS UMR7583, Université Paris Est Créteil, \\ Université Paris Diderot, Créteil, France \\ ${ }^{2}$ Harvard-Smithsonian Center for Astrophysics, Cambridge, Massachusetts, USA \\ ${ }^{3}$ Key Laboratory of Middle Atmosphere and Global Environment Observation, Institute of Atmospheric Physics (IAP), \\ Chinese Academy of Sciences, Beijing, China \\ ${ }^{4}$ Karlsruher Institut für Technologie (KIT), Institut für Meteorologie und Klimaforschung, Karlsruhe, Germany \\ ${ }^{5}$ RT Solutions Inc., Cambridge, Massachusetts, USA \\ Correspondence to: J. Cuesta (cuesta@lisa.u-pec.fr)
}

Received: 28 December 2012 - Published in Atmos. Chem. Phys. Discuss.: 30 January 2013

Revised: 12 June 2013 - Accepted: 12 August 2013 - Published: 2 October 2013

\begin{abstract}
We present a new multispectral approach for observing lowermost tropospheric ozone from space by synergism of atmospheric radiances in the thermal infrared (TIR) observed by IASI (Infrared Atmospheric Sounding Interferometer) and earth reflectances in the ultraviolet (UV) measured by GOME-2 (Global Ozone Monitoring Experiment2). Both instruments are onboard the series of MetOp satellites (in orbit since 2006 and expected until 2022) and their scanning capabilities offer global coverage every day, with a relatively fine ground pixel resolution $(12 \mathrm{~km}$-diameter pixels spaced by $25 \mathrm{~km}$ for IASI at nadir). Our technique uses altitude-dependent Tikhonov-Phillips-type constraints, which optimize sensitivity to lower tropospheric ozone. It integrates the VLIDORT (Vector Linearized Discrete Ordinate Radiative Transfer) and KOPRA (Karlsruhe Optimized and Precise Radiative transfer Algorithm) radiative transfer codes for simulating UV reflectance and TIR radiance, respectively. We have used our method to analyse real observations over Europe during an ozone pollution episode in the summer of 2009. The results show that the multispectral synergism of IASI (TIR) and GOME-2 (UV) enables the observation of the spatial distribution of ozone plumes in the lowermost troposphere (LMT, from the surface up to $3 \mathrm{~km}$ a.s.l., above sea level), in good agreement with the CHIMERE re-
\end{abstract}

gional chemistry-transport model. In this case study, when high ozone concentrations extend vertically above $3 \mathrm{~km}$ a.s.l., they are similarly observed over land by both the multispectral and IASI retrievals. On the other hand, ozone plumes located below $3 \mathrm{~km}$ a.s.l. are only clearly depicted by the multispectral retrieval (both over land and over ocean). This is achieved by a clear enhancement of sensitivity to ozone in the lowest atmospheric layers. The multispectral sensitivity in the LMT peaks at 2 to $2.5 \mathrm{~km}$ a.s.l. over land, while sensitivity for IASI or GOME-2 only peaks at 3 to $4 \mathrm{~km}$ a.s.l. at lowest (above the LMT). The degrees of freedom for the multispectral retrieval increase by 0.1 ( $40 \%$ in relative terms) with respect to IASI only retrievals for the LMT. Validations with ozonesondes (over Europe during summer 2009) show that our synergetic approach for combining IASI (TIR) and GOME-2 (UV) measurements retrieves lowermost tropospheric ozone with a mean bias of $1 \%$ and a precision of $16 \%$, when smoothing by the retrieval vertical sensitivity ( $1 \%$ mean bias and $21 \%$ precision for direct comparisons). 


\section{Introduction}

Tropospheric ozone is currently one of the air pollutants posing greatest threats to human health (e.g. Gryparis et al., 2004; and Ito et al., 2005) and ecosystems (e.g. Fuhrer and Achermann, 1994; USEPA, 1996; and EEA, 2011). Exposure to ground-level ozone may irritate the respiratory system, aggravate asthma and other lung diseases and even lead to premature mortality (e.g. WHO, 2003). The most important damage to ecosystems by air pollution is caused by ozone through eutrophication and acidification, leading to yield losses and damages to agricultural crops and forests (e.g. Fuhrer, 2009; Van Dingenen et al., 2009; and Hollaway et al., 2012). Ozone is a strong oxidizing agent that plays a central role in atmospheric photochemical processes (e.g. Seinfeld and Pandis, 1997). Tropospheric ozone is not directly emitted into the atmosphere but either formed by a chain of photochemical reactions following emissions of precursor gases near the surface (nitrogen oxides, carbon monoxide and volatile organic compounds, e.g. Crutzen et al., 1999) or transported from the stratosphere. Although emissions of most anthropogenic ozone precursors decreased substantially in the last decade in regions as Europe, this has not been reflected in observed annual average ozone concentrations (EEA, 2011).

Monitoring tropospheric ozone at the regional and global scale is a crucial societal issue. Only spaceborne remote sensing is capable of observing tropospheric ozone at such scales. New satellite-based instruments, such as the Infrared Atmospheric Sounding Interferometer (IASI) onboard MetOp satellites (Clerbaux et al., 2009), offer spatio-temporal coverage particularly appropriate for monitoring air quality and for synergism with regional chemistry-transport models. For improving air quality forecasting, comprehensive pollution monitoring systems integrate satellite observations and models for inter-validation (e.g. Zyryanov et al., 2012) or for full data assimilation (e.g. Coman et al., 2012). Still, current spaceborne observations show limited sensitivity for ozone in the lowermost troposphere (LMT, here defined from the surface up to $3 \mathrm{~km}$ of altitude), which is the major concern for air quality. State-of-the-art methods for observing ozone mainly use spaceborne observations from only one spectral domain, either ultraviolet (UV) or thermal infrared (TIR). They are based on high spectral resolution measurements in the UV from spaceborne instruments such as the Global Ozone Monitoring Experiment-2 (GOME-2, see EUMETSAT, 2006) onboard MetOp satellites or from the Ozone Monitoring Instrument (OMI, Levelt et al., 2006) onboard the Earth Observing System-Aura, EOS-Aura satellite (using approaches as e.g. Cai et al., 2012; and Liu et al., 2010). In the TIR, spaceborne ozone observations are derived from IASI onboard MetOp-A, the Tropospheric Emission Spectrometer (TES, Worden et al., 2007a) onboard EOS-Aura or the Interferometric Monitor for Greenhouse gases (IMG, Kobayashi et al., 1999) instrument on the platform ADEOS (by methods like e.g. Turquety et al., 2004; Coheur et al., 2005; Kulawik et al., 2006; Eremenko et al., 2008; and Dufour et al., 2012). In some cases, these approaches are used for air quality studies (e.g. Dufour et al., 2010), although they are mainly sensitive to ozone in the free troposphere (at 3 to $4 \mathrm{~km}$ of altitude at lowest).

A great potential for better probing lowermost tropospheric ozone from space is offered by combining the information provided by UV and TIR sounders aboard the same satellite. This is shown by simulation studies for currently inorbit satellites like EOS-Aura (Worden et al., 2007b; Landgraf and Hasekamp, 2007) and future missions as the GEOstationary Coastal and Air Pollution Events (GEO-CAPE) satellite (Fishman et al., 2012; Natraj et al., 2011). Only very recently, a multispectral retrieval method using UV and TIR real observations of respectively OMI and TES has shown agreement against 22 collocated ozonesonde measurements smoothed by the retrieval vertical sensitivity (with $9.7 \%$ mean bias and $26 \%$ precision in the LMT; Fu et al., 2013). Due to the limited spatial coverage of TES (no acrosstrack scanning is performed), this method was analysed in a profile-to-profile basis (Fu et al., 2013).

In this paper, we present a new multispectral approach to observe lowermost tropospheric ozone using the synergy of TIR atmospheric radiances observed by IASI and UV earth reflectances measured by GOME-2. Both instruments are onboard the MetOp satellite series (in orbit since 2006 and expected until 2022 with MetOp-C) and they are both well suited for monitoring air quality at regional and global scales resulting from their excellent scanning capabilities. They offer global coverage every day with a relatively fine ground resolution $(12 \mathrm{~km}$-diameter pixels spaced by $25 \mathrm{~km}$ for IASI at nadir and ground pixels of $80 \mathrm{~km} \times 40 \mathrm{~km}$ for GOME-2). This paper presents the capabilities of our new multispectral approach, so-called "IASI + GOME-2", to probe lowermost tropospheric ozone (here implemented with MetOp-A measurements of IASI and GOME-2) and its first application for ozone pollution studies. To the authors' knowledge, this is the first method combining real IASI and GOME-2 observations that shows good agreement with ozonesondes. The methodology implemented in the multispectral scheme of IASI+GOME-2 is described in Sect. 2. The performance of IASI + GOME-2 is described in Sect. 3 in terms of (i) spectral fitting, (ii) sensitivity enhancement of the IASI + GOME-2 with respect to single-spectral-band methods and (iii) a validation against ozonesondes (also compared to the single-band approaches). Section 4 presents an analysis of IASI + GOME-2 real observations for describing an ozone pollution outbreak over Europe in the summer of 2009. A comparison with the CHIMERE regional chemistrytransport model outputs (Sect. 4.2) confirms the capability of IASI + GOME-2 to describe the spatial distribution of lowermost tropospheric ozone plumes at the regional scale. 


\section{Multispectral scheme of IASI + GOME-2}

The IASI + GOME-2 multispectral scheme is constructed by adapting and merging together 2 state-of-the-art and thoroughly validated methods to retrieve ozone profiles using either only IASI observations in the spectral TIR region (described by Eremenko et al., 2008, hereafter referred as "IASI" method) or only GOME-2 measurements in the UV (called in the following "GOME-2" retrieval). This last one is based on Cai et al. (2012) for forward calculations, but here with a $1 / 8$ finer pixel resolution for spatial consistency with IASI pixels and a Tikhonov-Phillips-type regularization. In the next subsections, we describe how these 2 methods are joined together into the IASI + GOME-2 algorithm (Sect. 2.1) and the specific developments necessary for building this multispectral inversion approach (i.e. regularization constraints and adequate fitting variables, Sects. 2.2 and 2.3).

\subsection{Spectral measurements and forward simulations}

For the IASI + GOME-2 approach, a so-called measurement vector $\boldsymbol{y}_{\mathrm{UV}+\mathrm{TIR}}$ is built up by merging together IASI TIR atmospheric radiances $\boldsymbol{y}_{\text {TIR }}$ with GOME-2 UV earth reflectances $\boldsymbol{y}_{\mathrm{UV}}$, i.e. $\boldsymbol{y}_{\mathrm{UV}+\mathrm{TIR}}=\left[\begin{array}{ll}\boldsymbol{y}_{\mathrm{UV}}^{T} & \boldsymbol{y}_{\mathrm{TIR}}^{T}\end{array}\right]^{T}$ (with $T$ for transpose). For $\boldsymbol{y}_{\mathrm{TIR}}$, we use calibrated level 1C data (from http://www.pole-ether.fr/) and for $\boldsymbol{y}_{\mathrm{UV}}$ the ratio between backscattered radiance and solar irradiance calibrated level 1B spectra (from http://www.class.ncdc.noaa. gov/). The spectral resolutions of $\boldsymbol{y}_{\mathrm{TIR}}$ and $\boldsymbol{y}_{\mathrm{UV}}$ are respectively $0.5 \mathrm{~cm}^{-1}$ and $\sim 0.24 \mathrm{~nm}$ after convolution by the instrument response function and the sampling intervals are $0.25 \mathrm{~cm}^{-1}$ and $\sim 0.12 \mathrm{~nm}$. The criterion for combining IASI and GOME-2 spectra is based on the assumption that most sensitivity to ozone variability in the lowest atmospheric layers is likely provided by IASI measurements (as shown for single-band retrievals in Sects. 3.2 and 4). Thus, each IASI spectrum (12 km-diameter pixels) is matched with the co-located GOME- 2 spectrum (for $80 \mathrm{~km} \times 40 \mathrm{~km}$ pixels) without any averaging. Typically, the same $y_{\mathrm{UV}}$ is used 6 times with different $\boldsymbol{y}_{\mathrm{TIR}}$. Tropospheric ozone retrievals of IASI + GOME-2 are then calculated at the IASI ground resolution. For each IASI pixel, multispectral retrievals are processed independently.

For simulating $\boldsymbol{y}_{\mathrm{UV}+\mathrm{TIR}}$, we use 2 radiative transfer models: the line-by-line Karlsruhe Optimized and Precise Radiative transfer Algorithm (KOPRA, Stiller et al., 2000, 2002) for $\boldsymbol{y}_{\mathrm{TIR}}$ and the Vector Linearized Discrete Ordinate Radiative Transfer (VLIDORT, Spurr, 2006) code run in the full-polarization mode for $\boldsymbol{y}_{\mathrm{UV}}$. Following the IASI only approach, $\boldsymbol{y}_{\mathrm{TIR}}$ include 7 spectral micro-windows between 980 and $1070 \mathrm{~cm}^{-1}$. For $\boldsymbol{y}_{\mathrm{UV}}$, we consider 2 micro-windows between 290 and $345 \mathrm{~nm}$ accounting for the Hartley and Huggins bands (from respectively channels 1 and 2 of GOME-2, following Cai et al., 2012). GOME-2 measurements below $290 \mathrm{~nm}$ are not used due to lack of information on tropo- spheric ozone and low signal-to-noise ratios. The Jacobian matrix $\mathbf{K}_{\mathrm{UV}+\mathrm{TIR}}$ is set up by putting together the Jacobians calculated by each code, i.e. $\mathbf{K}_{\mathrm{UV}+\mathrm{TIR}}=\left[\mathbf{K}_{\mathrm{UV}}^{T} \mathbf{K}_{\mathrm{TIR}}^{T}\right]^{T}$. Analytical calculations are performed for geophysical variables (atmospheric profiles and surface properties) and finite differences for instrumental parameters (shifts and corrections, see Sect. 2.2). The radiometric error matrix $\mathbf{S}_{\mathrm{UV}+\mathrm{TIR}}^{\varepsilon}$ contains estimations of the radiometric noise variances for each element of $\boldsymbol{y}_{\mathrm{UV}+\mathrm{TIR}}$. For the TIR, the noise standard deviation is taken as $20 \mathrm{nW} /\left(\mathrm{cm}^{2} \mathrm{~cm}^{-1} \mathrm{sr}\right.$ ) (Eremenko et al., 2008). For the UV, noise is estimated for each wavelength using Müller matrix radiance response elements (Nowlan et al., 2011; Cai et al., 2012). Signal-to-noise ratios for GOME-2 are approximately a factor $1 / \sqrt{8}$ lower than for coarser pixels considered in Cai et al. (2012).

Ozone spectroscopic parameters used by IASI + GOME-2 are TIR atmospheric absorption line parameters taken from HITRAN 2004 (HIgh-resolution TRANsmission molecular absorption database; Rothman et al., 2005) and UV temperature-dependent cross sections from Brion et al. (1993, hereafter BRION1993). These spectroscopic parameters are used by validated single-band approaches (Eremenko et al., 2008; Cai et al., 2012) and also in Fu et al. (2013). Among several tests with different spectroscopic databases (see Sect. 3.3), only when using HITRAN 2004 and BRION1993 we obtain good agreement between IASI + GOME-2 retrievals in the troposphere and ozonesondes. Forward calculations consider as well the spectral signatures of $\mathrm{H}_{2} \mathrm{O}$ and $\mathrm{CO}_{2}\left(\mathrm{SO}_{2}\right.$ and $\left.\mathrm{NO}_{2}\right)$ for the TIR (UV). Except for $\mathrm{H}_{2} \mathrm{O}$ (see Sect. 2.3), climatological profiles are taken for the other trace gases.

For all profiles, the vertical grid is set between the surface and $60 \mathrm{~km}$ of altitude above sea level (a.s.l.), with steps of $1 \mathrm{~km}$ and $2 \mathrm{~km}$, respectively below and above $40 \mathrm{~km}$ of altitude. For each pixel, we use surface temperatures and atmospheric temperature profiles previously retrieved with KOPRA using IASI radiances (using as first guess meteorological analysis from the European Centre Medium-Range Weather Forecast, ECMWF). Following the Eremenko et al. (2008) approach, we use surface emissivity equal to unity and observations from the TIR atmospheric window (830$950 \mathrm{~cm}^{-1}$ ) for retrieving surface temperature and the $\mathrm{CO}_{2}$ band $\left(700-750 \mathrm{~cm}^{-1}\right)$ for the temperature profile. Partial cloud cover and aerosols are not explicitly modelled in KOPRA, but their effects in the IASI spectra are partially compensated by offsets for each TIR micro-window (Eremenko et al., 2008; Dufour et al., 2010).

In the UV spectra calculations, we treat pixels with partial cloud cover as a mixture of clear sky and cloudy scenes according to the independent pixel approximation (e.g. Cai et al., 2012). Cloud fractions (used as first guess) are derived by comparison between the reflectivity measured by GOME-2 at $347 \mathrm{~nm}$ (where ozone absorption is weak) for each pixel and those calculated for clear sky and fully cloudy 
conditions. Clouds are modelled as Lambertian surfaces with a reflectivity of $80 \%$ (Bhartia and Wellemeyer, 2002), located at the effective altitudes estimated by the FRESCO algorithm (Koelemeijer et al., 2001) using GOME-2 measurements of the $\mathrm{O}_{2} \mathrm{~A}$ band at $762 \mathrm{~nm}$. As a first guess for surface albedo in the UV, we extract the OMI climatology obtained by Kleipool et al. (2008) at $347 \mathrm{~nm}$. We use a single scattering rotational Raman scattering model (Sioris and Evans, 2000) for simulating the ring spectrum (filling in of solar Fraunhofer lines and telluric absorption structures by inelastic rotational Raman scattering). Using daily solar irradiance spectra observed by GOME-2, the instrument response is estimated as an asymmetric Gaussian slit function with width, shifts and asymmetric parameters adjusted for each wavelength (Cai et al., 2012) by comparison with a reference solar spectrum (Chance and Kurucz, 2010). Moreover, a "soft" recalibration is applied to each UV spectrum, which is derived on the basis of daily comparisons between measured and simulated reflectance as a function of wavelength and cross-track position (Cai et al., 2012). This recalibration improves the calibration consistency between channels 1 and 2 of GOME-2; and it decreases the fitting residuals of channel 2 by $30 \%$. It is also meant to reduce systematic biases on retrieved ozone profiles (up to $15 \%$ for GOME- 2 only retrievals, see Cai et al., 2012), which depend on cross-track position and instrument degradation with time. Aerosols are not modelled directly within VLIDORT, but their effects are partially taken into account by adjusting effective surface albedos and cloud fractions for each spectrum (Liu et al., 2010).

\subsection{Retrieved variables}

For each pixel, the IASI + GOME-2 retrieval scheme jointly retrieves the following state vector $\boldsymbol{x}_{\mathrm{UV}+\mathrm{TIR}}$ :

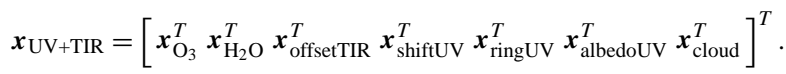

Thus we obtain the ozone profile $\boldsymbol{x}_{\mathrm{O}_{3}}$ (volume mixing ratios) by inverting $\boldsymbol{y}_{\mathrm{UV}+\mathrm{TIR}}$ and jointly adjusting the water vapour

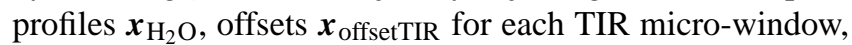
wavelength shifts $\boldsymbol{x}_{\text {shiftUV }}$ for the UV radiance and irradiance spectra (1 per UV channel), multiplicative factors of the ring spectrum $\boldsymbol{x}_{\text {ringUV }}$ ( 1 per UV channel), surface albedo multiplicative factors $\boldsymbol{x}_{\text {albedoUv }}$ (a constant for channel 1 of GOME-2 and 3 parameters of a second-degree polynomial function of wavelength for channel 2), and a factor for cloud fraction $\boldsymbol{x}_{\text {cloud }}$ used in the UV forward calculations. The multiplicative factors $\boldsymbol{x}_{\text {ringUV }}$ account for the multiple scattering contributions to the UV ring spectrum (e.g. Liu et al., 2010; and Cai et al., 2012).

First guess and a priori values for $\boldsymbol{x}_{\mathrm{O}_{3}}$ are taken from the climatology of McPeters et al. (2007). We extract one climatological $\boldsymbol{x}_{\mathrm{O}_{3}}$ for midlatitudes (averaged over $30-60^{\circ} \mathrm{N}$ ) and one for the tropics $\left(20-30^{\circ} \mathrm{N}\right)$. They are used alternatively for pixels with tropopause heights below $14 \mathrm{~km}$ a.s.l. (proxy for midlatitude air masses) or above (for tropical air masses, as done by Sellitto et al., 2013). Tropopause heights are derived from atmospheric temperature profiles retrieved from IASI spectra. For each pixel, we interpolate ECMWF analysis for obtaining first guess profiles for $\boldsymbol{x}_{\mathrm{H}_{2} \mathrm{O}}$. Initial values for $\boldsymbol{x}_{\text {offsetTIR }}$ and $\boldsymbol{x}_{\text {shiftUV }}$ are set to 0 and all multiplicative factors to 1 .

\subsection{Inversion and constraints}

To invert $\boldsymbol{y}_{\mathrm{UV}+\mathrm{TIR}}$, we implement a constrained least squares fit method using a Tikhonov-Phillips-type (Tikhonov, 1963; Kulawik et al., 2006) altitude-dependent regularization that optimizes sensitivity to lower troposphere ozone (as done for the TIR by Eremenko et al., 2008). It is numerically implemented using KOPRAFIT (the inversion module of KOPRA), adapted for the multispectral approach. The regularization matrix $\mathbf{R}_{\mathrm{UV}+\mathrm{TIR}}^{\mathrm{O}_{3}}$ constrains the zero, first and second order finite differences of the retrieved ozone profile, in adequacy with the information provided by $\boldsymbol{y}_{\mathrm{UV}+\mathrm{TIR}}$. As done by Kulawik et al. (2006) and Eremenko et al. (2008), the regularization matrix is not determined by prior knowledge on ozone vertical distributions (i.e. climatology), but it relies on the minimization of the retrieval errors and the maximization of the degrees of freedom. In our design, the strengths of the altitude-dependent constraints are a polynomial function of altitude (of fourth order), whose coefficients are derived by minimizing the following figure of merit:

$$
F=k_{1} \frac{s_{\mathrm{LMT}}^{\mathrm{tot}}}{\left(\mathrm{DOF}_{\mathrm{LMT}}\right)^{N}}+k_{2} \frac{s_{\mathrm{LT}}^{\mathrm{tot}}}{\left(\mathrm{DOF}_{\mathrm{LT}}\right)^{N}}+k_{3} \frac{s_{\mathrm{TOTAL}}^{\mathrm{tot}}}{\left(\mathrm{DOF}_{\mathrm{TOTAL}}\right)^{N}} .
$$

When minimizing $F$, we maximize the degrees of freedom while minimizing the total retrieval error simultaneously for several atmospheric columns. We consider the lowermost troposphere (LMT, below $3 \mathrm{~km}$ a.s.l.), the lower troposphere (below $6 \mathrm{~km}$ a.s.l., indicated LT in the following) and the total column (up to $60 \mathrm{~km}$ a.s.l., called here TOTAL). Degrees of freedom $\mathrm{DOF}_{\mathrm{col}}$ and estimates of total retrieval errors $s_{\mathrm{col}}^{\text {tot }}$ are calculated for the concerned atmospheric columns (indicated generally by the subscript $\mathrm{col}$ ). We choose the values of the coefficients $k_{1,2,3}$ and $N$ for approximately matching $s_{\mathrm{col}}^{\text {tot }}$ of IASI + GOME-2 with that for IASI only (detailed as LISA product in Dufour et al., 2012). In this way, the additional information provided by GOME-2 measurements will improve the vertical resolution or the degrees of freedom (without reducing the retrieval errors) of IASI + GOME-2 retrievals with respect to IASI only.

We estimate the total retrieval error matrix $\mathbf{S}^{\text {tot }}$ following Rodgers' (2000) formalism but replacing the prior covariance matrix by the regularization matrix $\mathbf{R}_{\mathrm{UV}+\mathrm{TIR}}^{\mathrm{O}_{3}}$ (as in e.g. Steck and von Clarmann, 2000; and Steck, 2002). The matrix $\mathbf{S}^{\text {tot }}$ is the sum of the retrieval errors due to smoothing $\mathbf{S}^{\text {smooth }}$, measurement noise $\mathbf{S}^{\text {mes }}$, cross-state uncertainties in water vapour $\mathbf{S}_{\mathrm{H}_{2} \mathrm{O}}^{\text {cross }}$ and other fitting variables $\mathbf{S}_{\text {param }}^{\text {cross }}$ (both calculated following Worden et al., 2007a) and systematic 
errors in carbon dioxide $\mathbf{S}_{\mathrm{CO}_{2}}^{\text {syst }}$ and atmospheric temperature $\mathbf{S}_{T}^{\text {syst }}$ profiles (other systematic errors are assumed negligible). As for TIR or UV only, $\mathbf{S}^{\text {smooth }}$ and $\mathbf{S}^{\text {mes }}$ are the principal contributions to $\mathbf{S}^{\text {tot }}$. For a partial atmospheric column $(\mathrm{col})$, we obtain $s_{\text {col }}^{\text {tot }}$ as the root sum of the diagonal elements of $\mathbf{S}^{\text {tot }}$ (as done by e.g. Steck, 2002; and Liu et al., 2010). We use $\mathrm{DOF}_{\mathrm{col}}$ to describe the sensitivity of the ozone retrieval (see Sect. 3.2), as it is the number of independent pieces of information available at each atmospheric column from the measurements. Following Rodgers (2000), it is calculated as the trace of the so-called averaging kernel matrix A (also called AVK) over the range of col. The AVK matrix represents the sensitivity of the retrieval to the true atmospheric state and it determines the smoothing of the retrieval. It is calculated by a classical expression using the TikhonovPhillips regularization matrix (e.g. Steck and von Clarmann, 2000; Steck, 2002; and Eremenko et al., 2008), here given for matrices of the multispectral approach,

$$
\begin{gathered}
\mathbf{A}=\left[\mathbf{K}_{\mathrm{UV}+\mathrm{TIR}}^{T}\left(\mathbf{S}_{\mathrm{UV}+\mathrm{TIR}}^{\varepsilon}\right)^{-1} \mathbf{K}_{\mathrm{UV}+\mathrm{TIR}}+\mathbf{R}_{\mathrm{UV}+\mathrm{TIR}}\right]^{-1} \\
\mathbf{K}_{\mathrm{UV}+\mathrm{TIR}}^{T}\left(\mathbf{S}_{\mathrm{UV}+\mathrm{TIR}}^{\varepsilon}\right)^{-1} \mathbf{K}_{\mathrm{UV}+\mathrm{TIR} .}
\end{gathered}
$$

We also characterize the height of maximum sensitivity to ozone $H_{\mathrm{col}}^{\mathrm{max}}$ for the partial column as the height of the maximum of the corresponding AVK (the sum of rows of $A$ for $c o l$ ). The constraints for the elements of $\boldsymbol{x}_{\mathrm{UV}+\mathrm{TIR}}$ (except for $\boldsymbol{x}_{\mathrm{O}_{3}}$ and $\boldsymbol{x}_{\mathrm{H}_{2} \mathrm{O}}$ ) are taken as 1 over the variance of each parameter. The adjustment of $\boldsymbol{x}_{\mathrm{H}_{2} \mathrm{O}}$ is included in the IASI + GOME-2 scheme in order to avoid aberrant retrievals of $\boldsymbol{x}_{\mathrm{O}_{3}}$ at the LT, which are obtained when the variability of $\mathrm{H}_{2} \mathrm{O}$ is not properly considered. For $\boldsymbol{x}_{\mathrm{H}_{2} \mathrm{O}}$, we use zero and first order constraints proportional to 1 over the variance of water vapour at each altitude (calculated from a $5 \mathrm{yr}$ climatology of radiosoundings at Paris).

In the following sections, all ozone retrievals use Tikhonov-Phillips-type regularization adapted for each spectral domain: $\mathbf{R}_{\mathrm{UV}+\mathrm{TIR}}^{\mathrm{O}_{3}}$ for IASI + GOME-2, $\mathbf{R}_{\mathrm{UV}}^{\mathrm{O}_{3}}$ for GOME2 only (also obtained by minimizing Eq. (2) but with $\boldsymbol{y}_{\mathrm{UV}}, \mathbf{K}_{\mathrm{UV}}, \mathbf{S}_{\mathrm{UV}}^{\varepsilon}$ and $\boldsymbol{x}_{\mathrm{UV}}$ in Eqs. (1) and (3)) and $\mathbf{R}_{\mathrm{TIR}}^{\mathrm{O}_{3}}$ for IASI only (used by Eremenko et al., 2008; and Dufour et al., 2012). For the 3 cases, the total retrieval error estimates $\mathbf{S}^{\text {tot }}$ are kept approximately similar. This leads to weaker multispectral ozone constraints in $\mathbf{R}_{\mathrm{UV}+\mathrm{TIR}}^{\mathrm{O}_{3}}$ than for single-band retrievals and provides a greater number of degrees of freedom than when using $\mathbf{R}_{\mathrm{UV}}^{\mathrm{O}_{3}}$ or $\mathbf{R}_{\mathrm{TIR}}^{\mathrm{O}_{3}}$. Note that IASI + GOME2 also gains sensitivity when using the same regularization matrix as for single-band retrievals (but less than with $\mathbf{R}_{\mathrm{UV}+\mathrm{TIR}}^{\mathrm{O}_{3}}$ ) through the complementarity of UV and TIR measurements to describe the vertical distribution of ozone.

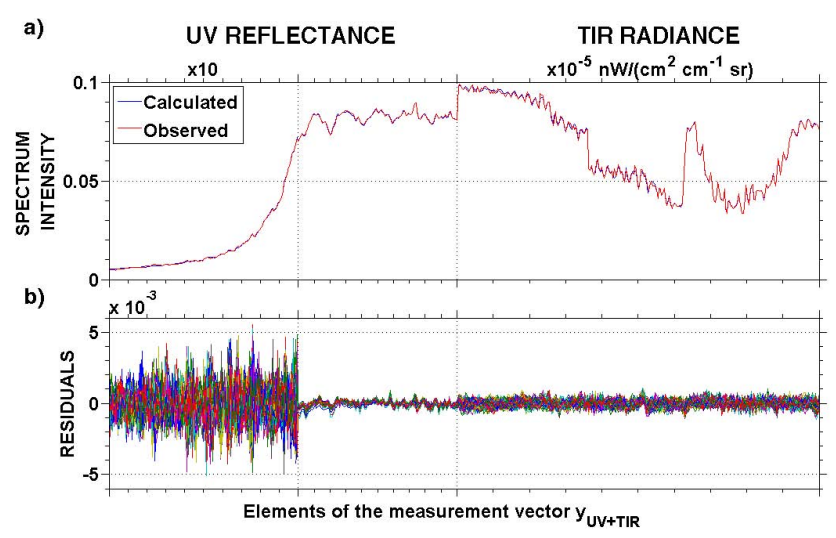

Fig. 1. Typical examples of co-localized radiance and reflectance spectra observed respectively by IASI and GOME-2 instruments and fitted by the IASI + GOME-2 approach. (a) Observed (red) and calculated (blue) elements in the IASI + GOME-2 measurement vector $\boldsymbol{y}_{\mathrm{UV}+\mathrm{TIR}}$ including UV reflectances in the Hartley (left, multiplied by 10) and Huggins (middle) bands and TIR radiances (right, divided by $10^{5}$ ). (b) Fitting residuals of 200 typical spectra in the same units as (a).

\section{Performance of IASI + GOME-2}

\subsection{Multiple spectral fitting}

As mentioned in Sect. 2, the IASI + GOME-2 measurement vector $\boldsymbol{y}_{\mathrm{UV}+\mathrm{TIR}}$ integrates coincident GOME-2 reflectances and IASI radiances (see an example in Fig. 1a). Different orders of magnitude in the intensities of the spectra and the measurement noise are present for shorter (channel 1) and longer (channel 2) UV wavelengths and TIR wavenumbers (Fig. 1 plots the successive elements in $y_{U V+T I R}$ and vertical dashed lines separate the 3 spectral regions). The IASI + GOME-2 approach simultaneously fits the whole $\boldsymbol{y}_{\mathrm{UV}+\mathrm{TIR}}$ within the uncertainties of each element, after 4 iterations. For pixels with low cloud fraction $(<30 \%)$, typical root-mean-square (RMS) spectral residuals between observed and fitted spectra are on average $\sim 9.5$ and $\sim 0.22 \%$ for respectively the shorter and longer UV wavelengths and $\sim 0.39 \%$ for TIR wavenumbers. Practically the same magnitudes of residuals are obtained when fitting independently $\boldsymbol{y}_{\mathrm{UV}}$ and $\boldsymbol{y}_{\mathrm{TIR}}$ for the single-band retrievals. For the TIR and shorter UV bands, residuals as a function of wavelength are mostly random (see examples in Fig. 1b) and near the magnitude of measurement noise ( $\sim 6 \%$ for the shorter UV and $\sim 0.3 \%$ for the TIR). Some systematic features are apparent for longer UV wavelengths, which are in the order of magnitude of radiometric noise $(\sim 0.3 \%$ or reflectance values of $\sim 3 \times 10^{-4}$ ) and equally apparent for GOME-2 only. They are probably linked to remaining errors in wavelength shifts and radiometric calibration (not fully corrected by the "soft" recalibration). 
Table 1. Sensitivity of the multispectral ozone retrieval IASI + GOME-2 (UV + TIR) and comparison with IASI (TIR) and GOME-2 (UV) only retrievals. Degrees of freedom for signal and the height of maximum sensitivity (km a.g.l.) are given for different atmospheric partial columns (LMT, LT, TROPO and TOTAL are respectively from the surface up to 3, 6, 12 and $60 \mathrm{~km}$ a.s.1.). Statistics are given in mean values and standard deviations (with respect to the average, in parenthesis) for all pixels over land and over ocean on 19-20 August 2009 for the region shown in Fig. 2. In order to compare partial columns of similar depths, we consider only land pixels with ground altitudes below $300 \mathrm{~m}$ a.s.l. For these pixels, the average thermal contrast is $4.4 \pm 2.4 \mathrm{~K}$ over land and $0.9 \pm 1.5 \mathrm{~K}$ over ocean.

\begin{tabular}{|c|c|c|c|c|c|c|c|}
\hline & & \multicolumn{2}{|c|}{ IASI + GOME-2 } & \multicolumn{2}{|c|}{ IASI } & \multicolumn{2}{|c|}{ GOME-2 } \\
\hline & $\begin{array}{l}\text { Atmospheric } \\
\text { column }\end{array}$ & Land & Ocean & Land & Ocean & Land & Ocean \\
\hline \multirow{4}{*}{$\begin{array}{l}\text { Degrees of freedom } \\
\text { for signal } \mathrm{DOF}_{\mathrm{col}}\end{array}$} & LMT & $\begin{array}{l}0.34 \\
( \pm 0.04)\end{array}$ & $\begin{array}{l}0.23 \\
( \pm 0.04)\end{array}$ & $\begin{array}{l}0.24 \\
( \pm 0.03)\end{array}$ & $\begin{array}{l}0.16 \\
( \pm 0.04)\end{array}$ & $\begin{array}{l}0.08 \\
( \pm 0.01)\end{array}$ & $\begin{array}{l}0.08 \\
( \pm 0.02)\end{array}$ \\
\hline & LT & $\begin{array}{l}0.75 \\
( \pm 0.05)\end{array}$ & $\begin{array}{l}0.64 \\
( \pm 0.05)\end{array}$ & $\begin{array}{l}0.62 \\
( \pm 0.03)\end{array}$ & $\begin{array}{l}0.52 \\
( \pm 0.04)\end{array}$ & $\begin{array}{l}0.25 \\
( \pm 0.03)\end{array}$ & $\begin{array}{l}0.24 \\
( \pm 0.04)\end{array}$ \\
\hline & TROPO & $\begin{array}{l}1.72 \\
( \pm 0.07)\end{array}$ & $\begin{array}{l}1.51 \\
( \pm 0.12)\end{array}$ & $\begin{array}{l}1.52 \\
( \pm 0.06)\end{array}$ & $\begin{array}{l}1.34 \\
( \pm 0.09)\end{array}$ & $\begin{array}{l}0.67 \\
( \pm 0.04)\end{array}$ & $\begin{array}{l}0.65 \\
( \pm 0.05)\end{array}$ \\
\hline & TOTAL & $\begin{array}{l}5.20 \\
( \pm 0.12)\end{array}$ & $\begin{array}{l}4.92 \\
( \pm 0.19)\end{array}$ & $\begin{array}{l}3.43 \\
( \pm 0.10)\end{array}$ & $\begin{array}{l}3.20 \\
( \pm 0.10)\end{array}$ & $\begin{array}{l}3.41 \\
( \pm 0.10)\end{array}$ & $\begin{array}{l}3.32 \\
( \pm 0.12)\end{array}$ \\
\hline \multirow{2}{*}{$\begin{array}{l}\text { Height of maximum } \\
\text { sensitivity } H_{\mathrm{col}}^{\max }\end{array}$} & LMT & $\begin{array}{l}2.20 \\
( \pm 0.50)\end{array}$ & $\begin{array}{l}3.42 \\
( \pm 0.59)\end{array}$ & $\begin{array}{l}3.02 \\
( \pm 0.67)\end{array}$ & $\begin{array}{l}4.26 \\
( \pm 0.51)\end{array}$ & $\begin{array}{l}3.68 \\
( \pm 0.50)\end{array}$ & $\begin{array}{l}3.64 \\
( \pm 0.65)\end{array}$ \\
\hline & LT & $\begin{array}{l}2.50 \\
( \pm 0.50)\end{array}$ & $\begin{array}{l}3.81 \\
( \pm 0.57)\end{array}$ & $\begin{array}{l}3.21 \\
( \pm 0.70)\end{array}$ & $\begin{array}{l}4.36 \\
( \pm 0.53)\end{array}$ & $\begin{array}{l}3.72 \\
( \pm 0.46)\end{array}$ & $\begin{array}{l}3.66 \\
( \pm 0.64)\end{array}$ \\
\hline
\end{tabular}

Figure $2 \mathrm{a}$ and $\mathrm{b}$ show the spatial distribution of IASI + GOME-2 fitting residuals over Europe on 19 August 2009, at the TIR and the UV Huggins bands (for qualitychecked pixels, see Sect. 3.3). Pixels from 2 satellite overpasses are shown (roughly east and west of $15^{\circ} \mathrm{E}$ ). For both spectral bands, residuals are rather homogeneously distributed at the regional scale and they mainly vary with the cross-track or swath position. Higher residuals are expected for significantly weaker signal intensities (measured by either IASI or GOME-2), for which signal-to-noise ratios are lower. This is the case of TIR radiances for viewing angles far from nadir (between 10 and $20^{\circ} \mathrm{E}$ and east of $5^{\circ} \mathrm{W}$ ) and also for lower surface temperatures (i.e. the Atlantic). Reflectances at the UV are about a factor $\sim 2$ lower for positions east of the satellite track (between 5 and $15^{\circ} \mathrm{E}$ and east of $30^{\circ} \mathrm{E}$ ). Higher UV residuals on the western part of the swath (over Spain and southeast of Italy) are likely linked to less effective "soft" corrections of the calibration errors for these cross-track positions. These distributions (Fig. 2a, b) are equally observed for the fitting residuals of the singleband retrievals (not shown). Moreover, similar residuals are obtained for $\boldsymbol{y}_{\mathrm{UV}+\mathrm{TIR}}$ constructed with different $\boldsymbol{y}_{\mathrm{TIR}}$ and the same $\boldsymbol{y}_{\mathrm{UV}}$ for all the analysed cases with low cloud fractions $(<30 \%)$.

Figure $2 \mathrm{~d}$ and $\mathrm{f}$ show co-located cloud fractions, surface emissivities and aerosol optical depths (the last 2 derived from MODIS satellite observations). No coincident patterns are clearly apparent between IASI + GOME-2 fitting residuals and the horizontal distribution of cloud fractions below $30 \%$ or high aerosol optical depths. Only some sparse pixels near thicker clouds (e.g. over the Atlantic or west of the Black sea) show higher residuals (either TIR or UV), which might have been missed by the cloud-screening checks (see Fig. 2c). Moreover, surface emissivity might not have a significant impact on the fitting residuals at the TIR, except over the Alps (see Fig. 2a, e).

\subsection{Sensitivity enhancement to lowermost tropospheric ozone}

The combination of the UV and TIR measurements in the IASI + GOME-2 approach allows a significant enhancement of sensitivity to ozone over the whole atmospheric column (see Table 1). The total column DOF TOTAL for IASI + GOME-2 is typically $\sim 5.2$ (on average for land pixels over Europe on 19-20 August 2009), thus 50\% higher than for IASI or GOME-2 only retrievals. Figure $3 \mathrm{a}$ and b show at which altitude levels the multispectral sensitivity gain is most significant, by comparing the AVKs diagonals averaged over land and over ocean (over Europe for 19-20 August 2009). With respect to IASI only, the sensitivity increase of IASI + GOME-2 is most important at the stratosphere ( DOF $_{\text {col }}$ above $20 \mathrm{~km}$ a.s.l. increases by $\sim 1.2$ ). In regard to GOME-2 only, IASI + GOME-2 is much more sensitive over the whole troposphere $\left(\mathrm{DOF}_{\mathrm{TROPO}}\right.$ is higher by $\sim 1.0$ ). When comparing at each altitude with respect to the most sensitive single-band retrieval, the multispectral gain of degrees of freedom is greater at both the lowest atmospheric layers (with +0.11 between 1 and $4 \mathrm{~km}$ a.s.l.) and the UTLS (upper troposphere/lower stratosphere, with +0.11 and +0.17 between 9 and $14 \mathrm{~km}$ a.s.l. over land and ocean, respectively). At the LMT, the mean DOF LMT $_{\text {for }}$ IASI + GOME- 2 is higher by at least 0.10 than for IASI only (and higher by 0.26 than for GOME-2 only see Table 1), both 

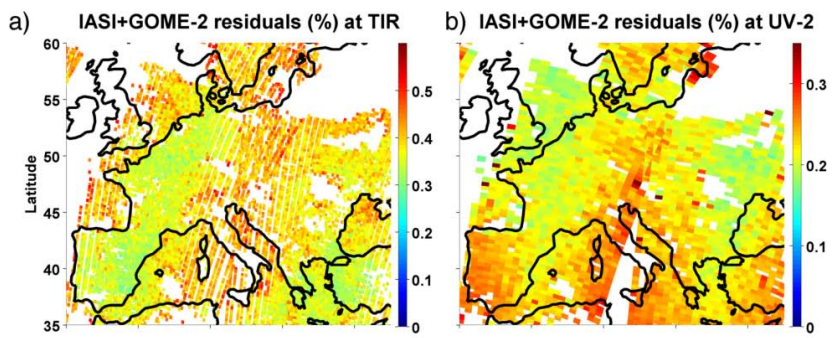

c)
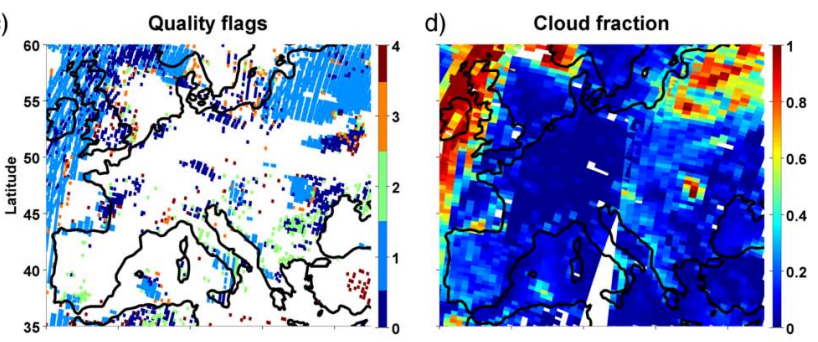

e) Surface emissivity at $1040 \mathrm{~cm}^{-1}$

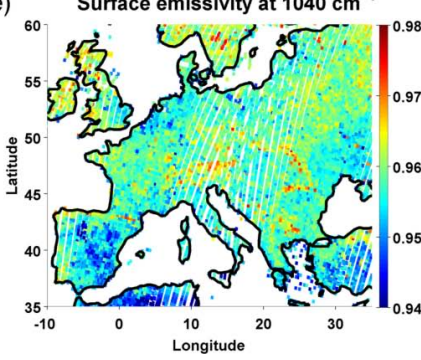

f) Aerosol Optical Depth at $\mathbf{5 5 0} \mathrm{nm}$

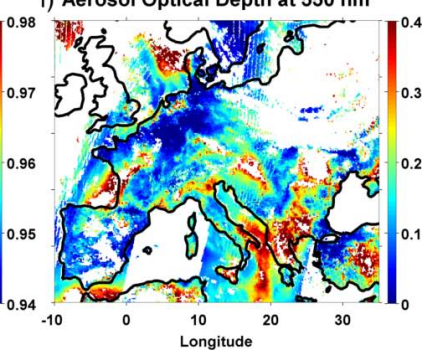

Fig. 2. Fitting residuals (in \%) of IASI + GOME-2 in the (a) TIR and (b) Huggins UV bands over Europe on 19 August 2009. (c) Quality flags for IASI + GOME-2 retrievals (0 indicates Planck function filter, 1 indicates cloud fractions $>0.3,2$ indicates surface temperature residuals $>0.7 \%, 3$ indicates ozone residuals $>0.7 \%$ and 4 indicates retrieved ozone $<0.1 \mathrm{ppb}$ or retrieved surface temperature $<274 \mathrm{~K}$ ). (d) Cloud fractions derived from FRESCO algorithm. (e) Surface emissivity at $1040 \mathrm{~cm}^{-1}$ retrieved from MODIS satellite measurements (Seeman et al., 2007; http://cimss.ssec.wisc.edu/iremis). (f) Aerosol optical depth at $550 \mathrm{~nm}$ from TERRA-MODIS L2 retrievals (http://modis-atmos.gsfc.nasa.gov/MOD04_L2).

over land and over ocean. This multispectral enhancement of sensitivity is the greatest over the atmospheric column in

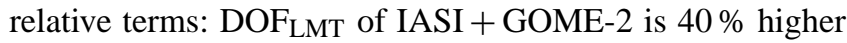
than IASI and a factor 3 higher than GOME-2. This is also illustrated in Fig. 4, which shows a comparison between typical AVKs up to $12 \mathrm{~km}$ a.s.l. for IASI + GOME-2 (red), IASI (green) and GOME-2 (blue) over land (top) and ocean (bottom). For the multispectral retrieval, a clear increase and shift of sensitivity (higher AVK values) towards the lowest layers of the troposphere are clearly depicted (particularly for the LMT over land, see Fig. 4a). In the example over land, IASI + GOME-2 AVKs for the lowest layers peak around $2 \mathrm{~km}$ a.s.l. (Fig. $4 \mathrm{a}$ ), thus $1 \mathrm{~km}$ below those for IASI (Fig. $4 \mathrm{~b}$ ) and $2 \mathrm{~km}$ below the ones for GOME-2 (Fig. 4c). Both over land and over ocean, we may notice 2 semi-independent partial columns ( 2 relative peaks, one up to $6 \mathrm{~km}$ a.s.l. and a sec-
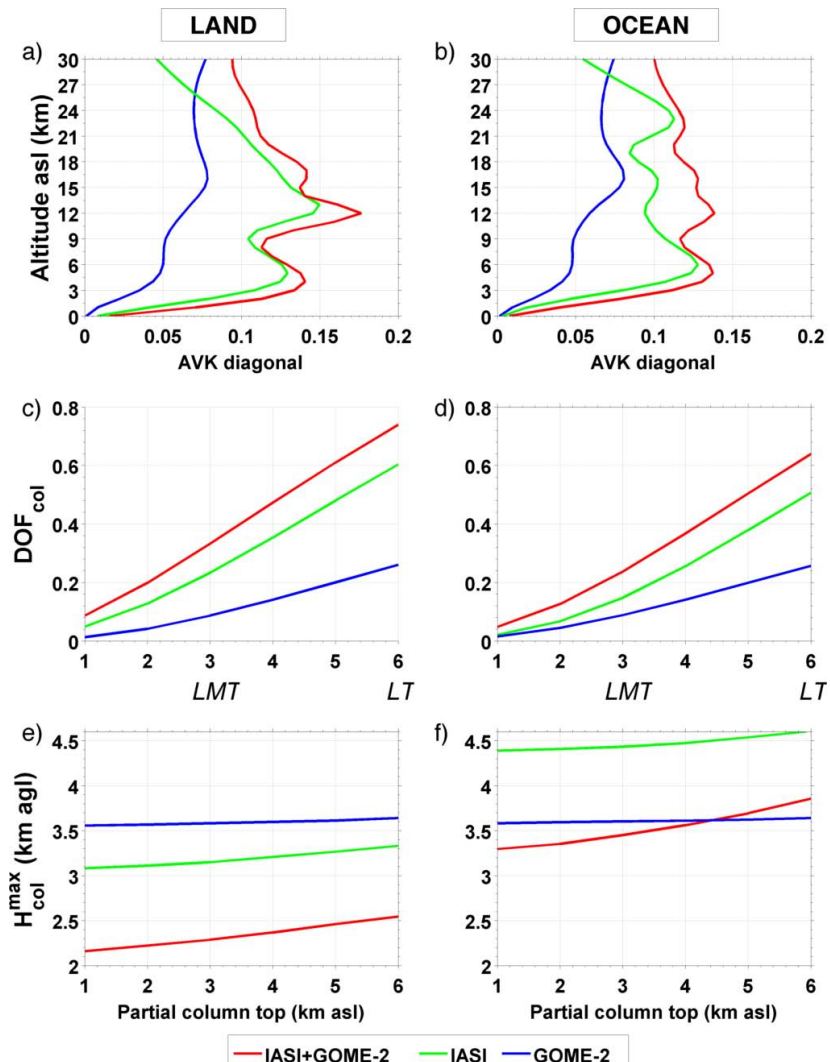

Fig. 3. Sensitivity comparison in terms of (a and $\mathbf{b}$ ) diagonals of AVKs as a function of altitude, (c and $\mathbf{d}$ ) degrees of freedom $\mathrm{DOF}_{\mathrm{col}}$ and (e and f) heights of maximum AVK (km a.g.l.) $H_{\mathrm{col}}^{\max }$, the last 2 for partial columns from the surface up to the altitude indicated in abscissa (from 1 to $6 \mathrm{~km}$ a.s.1.); for IASI + GOME-2 (red), IASI only (green) and GOME-2 (blue) ozone retrievals for an average of pixels over land (left) and over ocean (right) over Europe on 1920 August 2009.

ond one from 6 to $12 \mathrm{~km}$ a.s.l.) for IASI + GOME-2 (Fig. 4a, d). Except for IASI over land (Fig. 4b), the AVKs of the other single-band cases show a single large peak in the troposphere (see Fig. 4c, e and f). Figure $4 \mathrm{a}$ and $\mathrm{d}$ suggest as well that LMT ozone partial columns derived from IASI + GOME-2 are expected to also depend on ozone concentrations a few kilometres above the LMT (up to 5 or $6 \mathrm{~km}$ a.s.l. over land).

Figure $3 \mathrm{c}-\mathrm{f}$ quantify these features in terms of $\mathrm{DOF}_{\mathrm{col}}$ and $H_{\mathrm{col}}^{\max }$ for all partial columns from the surface up to each vertical level within the LT (from 1 up to $6 \mathrm{~km}$ a.s.l., on average, of land and ocean pixels over Europe for 19-20 August 2009). Over land, the $\mathrm{DOF}_{\mathrm{col}}$ for IASI + GOME- 2 are 0.04 , 0.10 and 0.13 higher than for IASI (and 0.08, 0.26 and 0.51 higher with respect to GOME-2, Fig. 3c) for respectively the partial columns up to $1 \mathrm{~km}$ a.s.l., $3 \mathrm{~km}$ a.s.l. (LMT) and $6 \mathrm{~km}$ a.s.l. (LT). The multispectral gain of degrees of freedom is relatively higher at the LMT than at the LT $\left(\mathrm{DOF}_{\mathrm{LMT}}\right.$ and DOF $_{\mathrm{LT}}$ are respectively 40 and $21 \%$ higher than IASI only). The mean DOF $_{\text {LMT }}$ for IASI + GOME-2 over land is $\sim 0.34$ 
a)
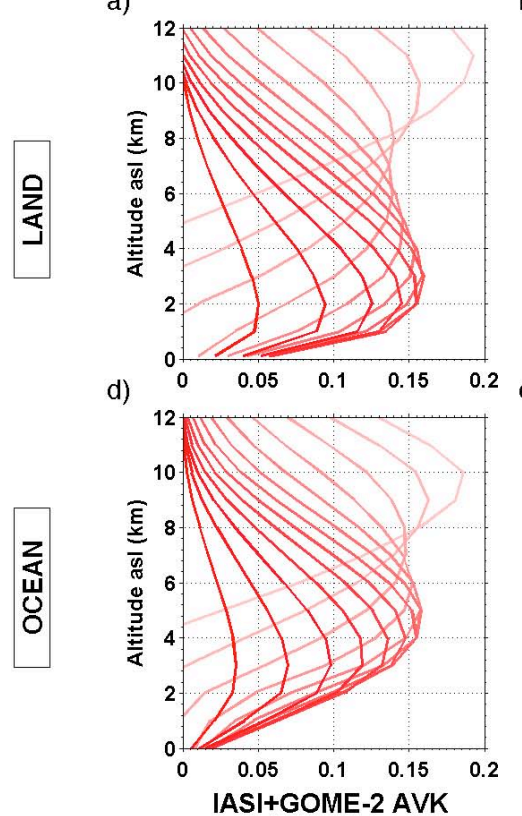

b)
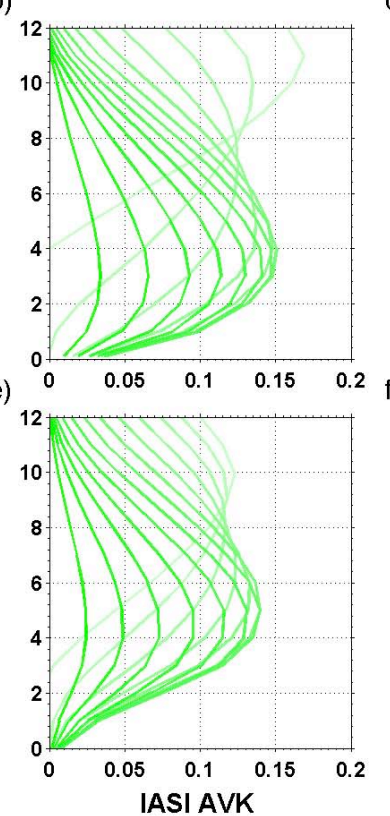

c)
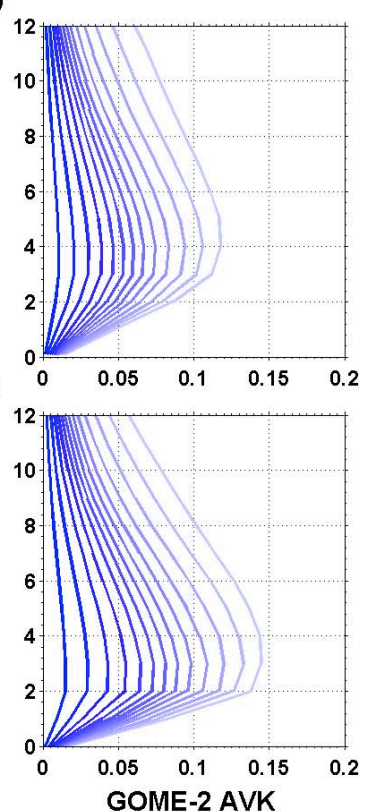

Fig. 4. Typical examples of AVKs between the surface and $12 \mathrm{~km}$ a.s.l. for (a and d) IASI + GOME-2, (b and e) IASI only and (c and $\mathbf{f})$ GOME-2 only ozone retrieval methods, over land (top) and over ocean (bottom). Lighter colours are given for AVK's rows at higher altitudes.

(Table 1), thus in the same order of magnitude as for the joint retrieval with TES and OMI $(\sim 0.37$ up to $700 \mathrm{hPa}$ which is at $3 \mathrm{~km}$ a.s.l. in a standard atmosphere; Fu et al., 2013).

For all partial columns in the LT, the height of maximum sensitivity $H_{\mathrm{col}}^{\max }$ of IASI + GOME-2 is $800-900 \mathrm{~m}$ below that for IASI both over land and over ocean (and $1.3 \mathrm{~km}$ below that for GOME-2 over land, see Fig. 3e and f). Sensitivity maxima for IASI and GOME-2 are at lowest at 3.0 and 3.7 $\mathrm{km}$ above ground level (a.g.l.). In this case, averaging kernels for all levels within the LMT peak above the LMT partial column. For IASI + GOME-2, the sensitivity peak height $H_{\mathrm{LMT}}^{\mathrm{max}}$ over land is located on average at $\sim 2.2 \mathrm{~km}$ a.g.l. (Table 1), thus within the LMT partial column itself. Over ocean, IASI + GOME-2 sensitivity within the LT peaks at similar heights as for GOME-2 (3.4-3.8 km a.s.l., Fig. 3f) but with a gain of $\mathrm{DOF}_{\mathrm{LT}}$ of $+0.4(+160 \%)$.

Figure 5 presents the geographical distribution of $\mathrm{DOF}_{\mathrm{LT}}$ and $H_{\mathrm{LT}}^{\max }$ over Europe for 19 August 2009. The gain of sensitivity of IASI + GOME-2, both for $\mathrm{DOF}_{\mathrm{LT}}$ and $H_{\mathrm{LT}}^{\max }$, is consistently observed over the whole continent (Fig. 5). Sensitivity dependence between land and ocean is apparent for IASI only and also for IASI + GOME-2 retrievals, due to different thermal contrasts (differences between the temperature of the surface and the lowest atmospheric layer). Over ocean, where IASI only LT sensitivity peaks around $6 \mathrm{~km}$ a.g.l., IASI + GOME-2 performance is similar to that for IASI over land (both for $\mathrm{DOF}_{\mathrm{LT}}$ and $H_{\mathrm{LT}}^{\max }$, see also Table 1). For GOME-2 only (Fig. 5e), sensitivity changes less between land and ocean, but with regional enhancements of DOF $\mathrm{LT}_{\mathrm{LT}}$ (e.g. at $45-50^{\circ} \mathrm{N}, 20^{\circ} \mathrm{E}$ and $38-45^{\circ} \mathrm{N}, 8^{\circ} \mathrm{W}$ in Fig. 5e) likely due to higher reflectivities induced by the presence of clouds (Fig. 2d) at low levels (below $2 \mathrm{~km}$ a.s.1.). Higher spatial variability is observed for $H_{\mathrm{LT}}^{\max }$ (Fig. 5, right panels) than for DOF $_{\mathrm{LT}}$ (Fig. 5, left panels), depending on the atmospheric and surface conditions. For southern (western) European regions over land as Spain (France), relatively high (moderate) surface temperatures and thermal contrasts of $11.5 \mathrm{~K}$ $(2.4 \mathrm{~K})$ induce $H_{\mathrm{LT}}^{\max }$ of $\sim 1.9 \mathrm{~km}$ a.g.l. $(\sim 2.8 \mathrm{~km}$ a.g.l.) for IASI + GOME-2 whereas $\sim 2.4 \mathrm{~km}$ a.g.l. $(\sim 3.8 \mathrm{~km}$ a.g.l. $)$ for IASI only.

For the LMT partial column (Fig. 6), the sensitivity enhancement of IASI + GOME-2 with respect to IASI is more marked than for the LT over the whole continent. For the single-band approaches, $H_{\mathrm{LMT}}^{\max }$ and $H_{\mathrm{LT}}^{\max }$ are practically the same (Figs. 5d and 6d, 5f and 6f). On average over land, $H_{\mathrm{LMT}}^{\max }$ for IASI + GOME-2 is located at $2.2 \mathrm{~km}$ a.g.1. $(300 \mathrm{~m}$ below $H_{\mathrm{LT}}^{\max }$ ), thus 0.8 and $1.3 \mathrm{~km}$ below $H_{\mathrm{LMT}}^{\max }$ for IASI and GOME-2, respectively. For different regions, $H_{\mathrm{LMT}}^{\mathrm{max}}$ for IASI + GOME-2 varies significantly, reaching for example $\sim 1.6 \mathrm{~km}$ a.g.l. in Spain and $\sim 2.6 \mathrm{~km}$ a.g.l. in France, thus depending on the main conditions driving the sensitivity of the single-band retrievals. For all pixels in Fig. 6 with simultaneously higher thermal contrasts (from 10 to $15^{\circ} \mathrm{C}$ ) and higher cloud fractions (from 0.2 to 0.3 ), $H_{\mathrm{LMT}}^{\mathrm{max}}$ for IASI + GOME-2 is on average $1.8 \mathrm{~km}$ a.g.l., thus respectively 0.9 and $2.0 \mathrm{~km}$ below that for IASI and GOME-2. For both negative thermal contrasts (from -10 to $-5^{\circ} \mathrm{C}$ ) and lower cloud fraction (below 0.1), the multispectral sensitivity maximum at the LMT peaks at $3.6 \mathrm{~km}$ a.g.l., which is 1.5 and $0.7 \mathrm{~km}$ below that for IASI and GOME-2 only, respectively. Moreover, 

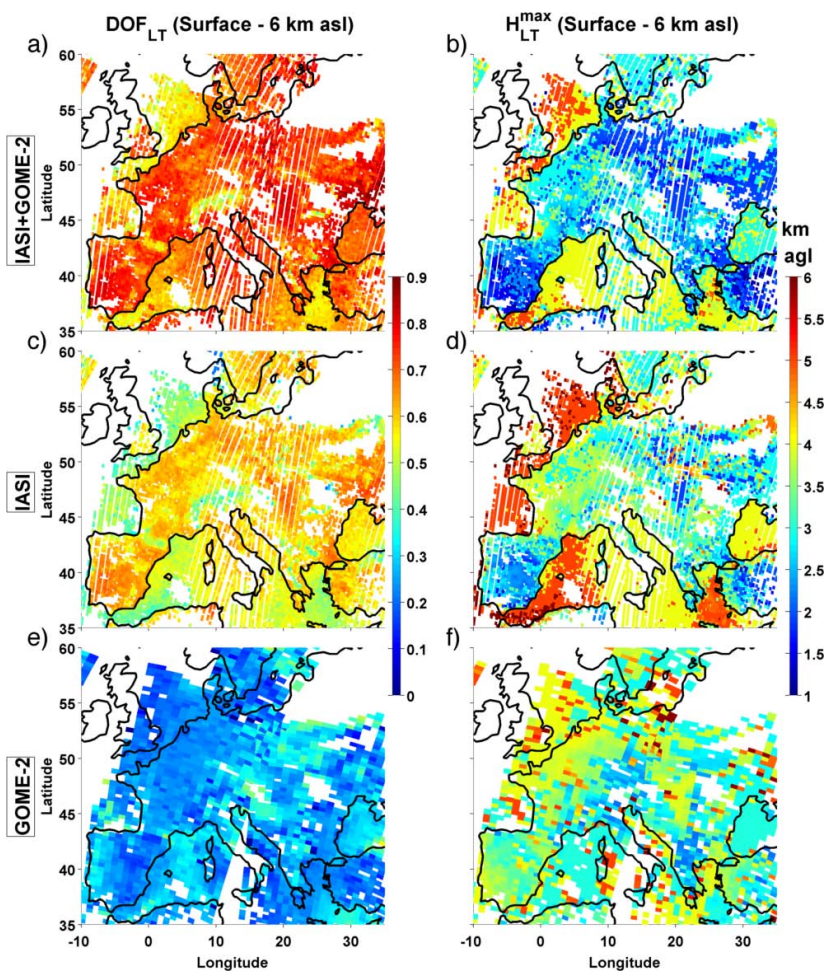

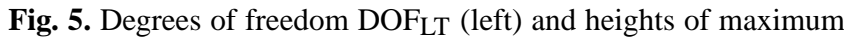
AVK (km a.g.l.) $H_{\mathrm{LT}}^{\max }$ (right) in the lower troposphere (LT, from the surface up to $6 \mathrm{~km}$ a.s.1.) for (a and b) IASI + GOME-2, (c and d) IASI only and (e and f) GOME-2 only ozone retrievals over Europe on 19 August 2009.

the multispectral gain of sensitivity at the LMT is particularly advantageous for compensating the lack of sensitivity of one of the single-band retrievals. In fact, for all pixels with negative thermal contrasts (from -10 to $-5^{\circ} \mathrm{C}$ ), $H_{\mathrm{LMT}}^{\max }$ for IASI + GOME-2 is on average $1.7 \mathrm{~km}$ below that for IASI. For all cases over land with low cloud fractions (below 0.1), the multispectral $H_{\mathrm{LMT}}^{\max }$ is located $1.8 \mathrm{~km}$ below that for GOME-2. On the contrary, the sensitivity enhancement of IASI + GOME-2 may be relatively less significant with respect to IASI or GOME-2 in conditions of high sensitivity. Indeed, the multispectral $H_{\mathrm{LMT}}^{\mathrm{max}}$ is located $0.7 \mathrm{~km}$ below that for IASI for high thermal contrasts (from 10 to $15^{\circ} \mathrm{C}$ ) and also $0.7 \mathrm{~km}$ below that for GOME- 2 over land for higher cloud fractions (from 0.2 to 0.3 )

\subsection{Validation against ozonesondes}

In this section, we analyse the quality of the IASI + GOME-2 ozone retrieval by comparison with reference ozonesonde measurements and we evaluate the results against those obtained by the single-band retrievals with the same data sets. We consider all ozonesondes provided by the World Ozone and Ultraviolet radiation Data Centre (WOUDC, http://www. woudc.org) for the summer 2009 from 10 different launch-

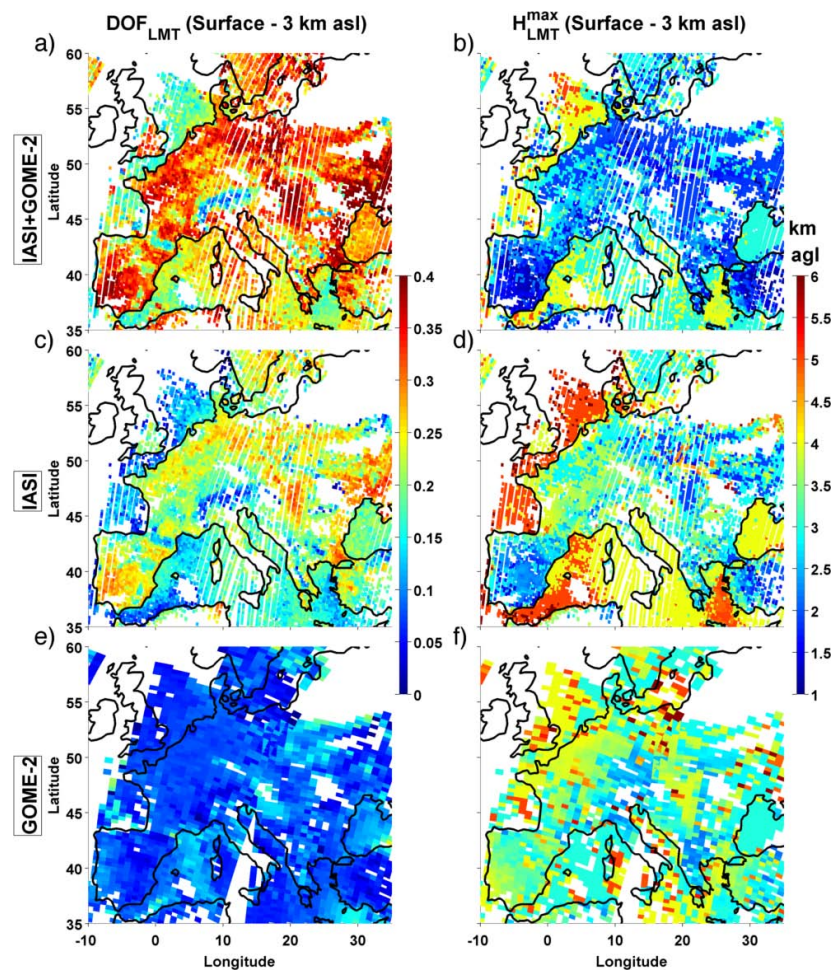

Fig. 6. Same as Fig. 4, but for the lowermost troposphere (LMT, from the surface up to $3 \mathrm{~km}$ a.s.1.).

ing sites (spread from 40 to $60^{\circ} \mathrm{N}$ ): Ankara (Turkey), De Bilt (Holland), Hohenpeissenberg (Germany), Legionowo (Poland), Lerwik (Scotland), Lindenberg (Germany), Madrid (Spain), Payerne (Switzerland), Uccle (Belgium) and Valentia (Ireland). The accuracy of the ozone concentration measurement is expected to reach $\pm 5 \%$ (Deshler et al., 2008), as most ozonesondes use the electrochemical concentration cell technique (except for Hohenpeissenberg with Brewer Mast sondes). Ozonesonde profiles have a vertical resolution of about $\sim 150 \mathrm{~m}$ and typically extend from the surface up to $30 \mathrm{~km}$ a.s.l. For the comparison, we follow the methodology used for validating several IASI scientific ozone products (Keim et al., 2009; Dufour et al., 2012). Coincidence criteria are spatial co-localization within $\pm 110 \mathrm{~km}$ and a time frame of $7 \mathrm{~h}$ from the MetOp-A morning overpass (at 09:30 LT). The comparison is made for each ozonesonde with the average of collocated satellite retrievals (thus partly reducing random errors). For comparisons accounting for the retrieval sensitivity, we calculate "smoothed" ozonesonde profiles by convoluting with each of the AVKs of the collocated satellite retrievals and then taking the average.

We only use IASI + GOME-2 pixels with low cloud fraction $(<30 \%)$ that pass a series of quality checks (applied simultaneously for the 3 satellite retrievals). These tests verify the consistency of IASI spectra at the TIR atmospheric window with respect to Planck functions of possible surface temperatures and also discard pixels with too high fitting 
Table 2. Validation of IASI + GOME-2 ozone retrievals against ozonesonde measurements smoothed by IASI + GOME-2 averaging kernels We consider 105 ozonesondes launched between June and August 2009 from 10 stations over Europe. Cloudy pixels and aberrant satellite retrievals (both for the multispectral and the single-band approaches) are screened out. The comparison is expressed in Dobson units (DU) and in percentage (in parenthesis) in terms of mean bias, RMS differences, linear correlation coefficients $R$ and retrieval standard deviations normalized by those of ozonesonde measurements $|\sigma|$.

\begin{tabular}{cllll}
\hline \multicolumn{5}{c}{$\begin{array}{l}\text { Validation of IASI + GOME-2 ozone retrieval vs. } \\
\text { ozonesondes smoothed by the retrieval AVK }\end{array}$} \\
\hline Atmospheric column & Bias & RMS & $R$ & $|\sigma|$ \\
LMT & $0.1(0.6 \%)$ & $1.8(17.0 \%)$ & 0.84 & 1.1 \\
LT & $-0.2(-0.8 \%)$ & $3.9(17.4 \%)$ & 0.68 & 1.1 \\
TROPO & $-2.0(-4.5 \%)$ & $6.4(14.0 \%)$ & 0.90 & 0.78 \\
UPTO30 & $6.2(2.5 \%)$ & $13.8(5.6 \%)$ & 0.95 & 0.91 \\
\hline
\end{tabular}

Table 3. Direct comparison of IASI + GOME-2 ozone retrievals against raw ozonesonde measurements. The same as Table 2 but without smoothing ozonesonde profiles with IASI + GOME-2 averaging kernels. We also provide estimations of the total and smoothing retrieval errors, $s_{\mathrm{col}}^{\mathrm{tot}}$ and $s_{\mathrm{col}}^{\text {smooth }}$, for the IASI + GOME-2 retrievals used in the comparison.

\begin{tabular}{cllllll}
\hline \multicolumn{6}{c}{ Direct comparison of IASI + GOME-2 ozone retrieval vs. raw ozonesondes } \\
\hline Atmospheric column & Bias & RMS & $R$ & $|\sigma|$ & $s_{\text {col }}^{\text {tol }}$ & $s_{\text {col }}^{\text {smooth }}$ \\
LMT & $0.1(1.1 \%)$ & $2.3(22.0 \%)$ & 0.76 & 0.94 & $2.0(19.6 \%)$ & $1.8(17.2 \%)$ \\
LT & $0.01(0.1 \%)$ & $4.2(19.2 \%)$ & 0.62 & 1.04 & $2.6(11.9 \%)$ & $2.2(10.0 \%)$ \\
TROPO & $-0.73(-1.7 \%)$ & $6.2(14.0 \%)$ & 0.89 & 0.81 & $3.8(8.7 \%)$ & $3.3(7.4 \%)$ \\
UPTO30 & $5.9(2.4 \%)$ & $13.8(5.6 \%)$ & 0.95 & 0.93 & $7.4(3.0 \%)$ & $6.2(2.5 \%)$ \\
\hline
\end{tabular}

residuals (for the retrievals of surface temperatures and ozone profiles) or aberrant results (i.e. surface temperatures below $273 \mathrm{~K}$ or ozone mixing ratios below $0.1 \mathrm{ppb}$ ). For illustration, Fig. $2 \mathrm{c}$ shows the results of these quality checks for $19 \mathrm{Au}-$ gust 2009 over Europe. In this case, $68 \%$ of the pixels passed the tests, $18 \%$ correspond to cloud fractions greater than 0.3 , $9 \%$ are screened out by the Plank function filter and the rest are removed by the filters of high fitting residuals $(4 \%)$ or aberrant results $(1 \%)$. For all cases of this validation study (during summer 2009 over Europe), these quality tests are passed by typically 7-12 satellite retrievals that are collocated with each ozonesonde.

The IASI + GOME-2 validation results are summarized in Tables 2 and 3. For comparison, the same results but for the single-band retrievals are presented in Tables 4 and 5 (considering the same pixels and ozonesondes). The number of days with coincident IASI and GOME-2 pixels with ozonesondes is 42 and the number of ozonesondes after screening cloudy scenes and aberrant retrievals is 105 . The average profile of the ozonesondes is similar to the average profile used as a priori for the retrievals (differences are below $2 \%$ for the LMT and the LT). Tables 2 and 4 consider ozonesonde profiles smoothed by the retrievals' AVKs, and Tables 3 and 5 account for raw ozonesone measurements. These comparisons are also presented graphically in terms of mean bias (Fig. 7) and Taylor diagrams summarizing variability, linear correlation and centred RMS differences (Fig. 8), for 3 tropospheric partial columns. The re- sults show very good agreement between IASI + GOME-2 retrievals and ozonesondes (both smoothed by the retrieval AVKs and raw measurements), particularly in terms of mean biases and standard deviations (see Tables 2 and 3). In regard to the single-band retrievals (Tables 4 and 5, see also Figs. 7 and 8), only IASI + GOME-2 is capable of reproducing the mean ozone concentrations (mean biases $<1 \%$ ) and the variability (within $\pm 10 \%$ ) observed by the ozonesondes (both smoothed and raw) at the LMT and the LT. The single-band retrievals show a negative bias for the LMT and LT concentrations (from -5 to $-11 \%$, see Fig. $7 \mathrm{a}$ and b) and they significantly underestimate the standard deviation (from -21 to $-40 \%$ at the LMT, see Fig. 8a-d) with respect to ozonesondes (both smoothed and raw). For higher LMT ozone concentrations ( $>10 \mathrm{DU}$, i.e. the average for raw ozonesondes), negative biases at the LMT are significantly greater for IASI $(-20 \%)$ and GOME-2 $(-12 \%)$, while it remains moderate for IASI + GOME-2 $(-4 \%)$. Too low standard deviations and greater negative biases for higher ozone concentrations are probably both linked to the lower sensitivity of the single-band retrievals to LMT ozone.

The precision of the retrievals, expressed in RMS differences with respect to the ozonesondes, is very similar for the 3 satellite observations ( $\sim 17$ and $\sim 22 \%$ at the LMT respectively for smoothed and raw ozonesondes, Tables 2-5), as expected by the design of the regularization matrices of each approach (i.e. similar total retrieval errors). Linear correlations with respect to raw ozonesonde measurements at 
Table 4. Comparison of IASI only (left) and GOME-2 only (right) ozone retrievals against ozonesonde measurements smoothed by averaging kernels of the retrievals. The same conventions, pixels and ozonesondes as in Table 2 are used.

\begin{tabular}{cllll}
\multicolumn{5}{c}{ Comparison of IASI only/GOME-2 only ozone retrieval vs. ozonesondes smoothed by the retrieval AVK } \\
\hline Atmospheric column & Bias & RMS & $R$ & $|\sigma|$ \\
\hline LMT & $-1.0 /-0.7(-10.2 \% /-6.2 \%)$ & $1.8 / 1.7(17.3 \% / 16.7 \%)$ & $0.88 / 0.90$ & $0.70 / 0.77$ \\
LT & $-1.9 /-1.8(-8.7 \% /-8.0 \%)$ & $4.0 / 4.3(18.5 \% / 19.4 \%)$ & $0.69 / 0.78$ & $0.64 / 0.72$ \\
TROPO & $-0.1 /-5.4(-0.3 \% /-11.4 \%)$ & $6.5 / 10.1(14.4 \% / 21.8 \%)$ & $0.89 / 0.80$ & $0.70 / 0.72$ \\
UPTO30 & $-3.0 / 5.4(-1.2 \% / 2.2 \%)$ & $12.7 / 14.5(5.1 \% / 5.7 \%)$ & $0.95 / 0.95$ & $0.95 / 0.88$ \\
\hline
\end{tabular}

Table 5. Direct comparison of IASI only (left) and GOME-2 only (right) ozone retrievals against raw ozonesonde measurements. The same as Table 3 but without smoothing ozonesonde profiles with retrieval averaging kernels.

\begin{tabular}{clllll}
\hline \multicolumn{5}{c}{ Direct comparison of IASI only/GOME-2 only ozone retrieval vs. raw ozonesondes } \\
\hline Atmospheric column & Bias & RMS & $R$ & $|\sigma|$ \\
LMT & $-1.3 /-0.5(-12.6 \% /-4.5 \%)$ & $2.4 / 2.4(23.3 \% / 22.5 \%)$ & $0.78 / 0.73$ & $0.60 / 0.79$ \\
LT & $-2.5 /-1.3(-11.2 \% /-5.8 \%)$ & $4.5 / 4.8(20.4 \% / 21.6 \%)$ & $0.56 / 0.43$ & $0.67 / 0.93$ \\
TROPO & $0.5 /-2.7(1.2 \% /-6.1 \%)$ & $6.3 / 10.1(14.1 \% / 22.8 \%)$ & $0.89 / 0.67$ & $0.72 / 0.79$ \\
UPTO30 & $-3.2 / 4.9(-1.3 \% / 2.0 \%)$ & $13.4 / 14.4(5.4 \% / 5.8 \%)$ & $0.95 / 0.94$ & $0.97 / 0.93$ \\
\hline
\end{tabular}

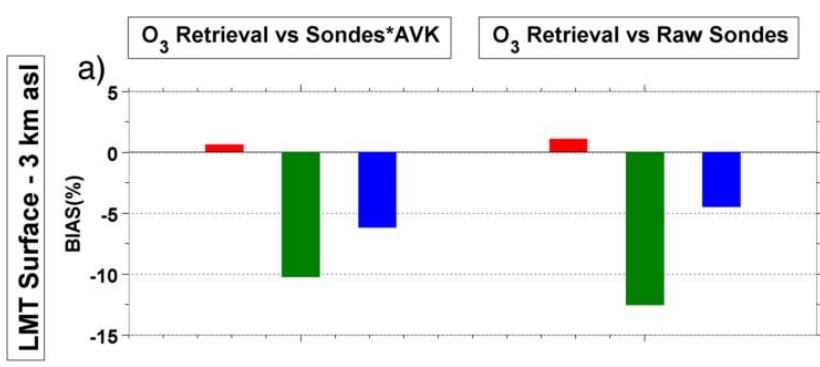

b)

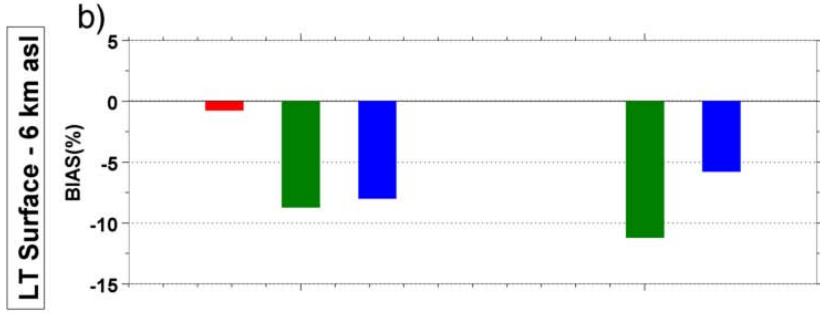

c)

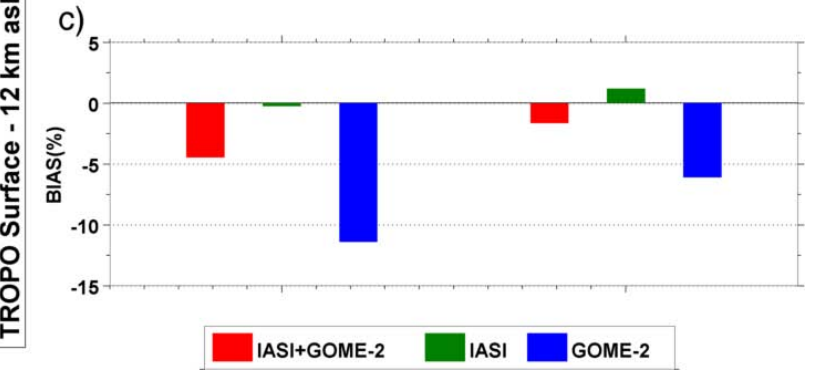

Fig. 7. Mean bias between ozone retrievals from IASI + GOME-2 (red), IASI (green) and GOME-2 (blue) and 105 ozonesondes during summer 2009 over Europe (smoothed by the retrievals' AVKs on the left and direct comparisons on the right) for the (a) LMT, (b) LT and (c) TROPO partial columns. the LMT are fairly similar for the 3 satellite products (from 0.73 to 0.78 , Tables 3 and 5), but only IASI + GOME- 2 reproduces as well the variability measured by the ozonesondes (Fig. 8b). When comparing against LMT concentrations from smoothed ozonesondes (Fig. 8a), relatively high linear correlations are remarked for the 3 satellite observations ( 0.84 for IASI + GOME- 2 and 0.89 for the single-band retrievals). Note that in this case the altitude at which the comparison against the smoothed ozonesondes is effectively made is $H_{\mathrm{LMT}}^{\mathrm{max}}$, thus it differs from one satellite retrieval to the other. Moreover, the validation results for IASI + GOME2 are consistent for different cloud cover conditions. For cloud fraction below 0.1 (thus considering 67 ozonesondes), the multispectral LMT retrievals present a mean bias below $2 \%$, a standard deviation within $10 \%$ of that for ozonesondes, RMS differences of $15 \%(22 \%)$ and linear correlations of $0.89(0.79)$ with respect to smoothed (raw) ozonesondes.

As for the LMT, comparisons at the LT partial column show as well very low mean biases and variabilities consistent with ozonesondes for IASI + GOME-2 and underestimations for the single-band approaches (Figs. 7b and 8c, d). For IASI + GOME-2 and IASI only, linear correlations at the LT are rather lower $(\sim 0.7$ and $\sim 0.6$ respectively when smoothing and for direct comparisons) but with similar relative behaviour as for the LMT. At the TROPO partial column (Figs. 7c and 8e, f), IASI + GOME-2 and IASI show similarly good agreement with ozonesondes (correlations of 0.89 and RMS differences of $14 \%)$, but the RMS differences are higher for GOME-2 ( 22\%). Integrated ozone up to $30 \mathrm{~km}$ a.s.l. (UPTO30) derived from the satellite observations agrees with ozonesondes with mean biases ranging from $-1.3 \%$ (IASI) to $+2.5 \%$ (IASI + GOME-2) . 

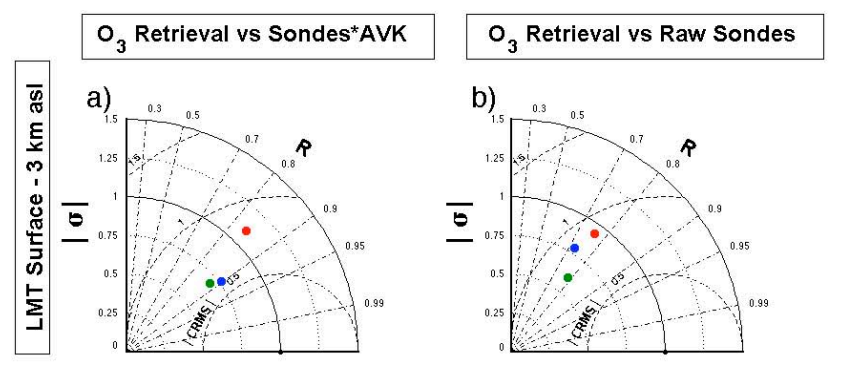

Table 6 presents additional tests on the potential effects on the multispectral ozone retrieval due to inconsistencies in the UV/TIR spectroscopic parameters. According to laboratory studies, spectral discrepancies between UV crosssection databases and TIR line intensities (e.g. HITRAN 2004) may reach 4-5\% (Picquet-Varrault et al., 2005; Gratien et al., 2010). The consequences of such incompatibilities are not straightforward, since several fitting parameters modify the absolute calibration of the spectra (i.e. TIR spectral offsets, fitting effective UV surface albedos and UV soft recalibration). Thus, we verify the overall effects by comparing ozonesonde measurements (105 sondes) with the multispectral ozone retrieval either using HITRAN 2000 (with TIR line intensities approximately $+4 \%$ higher than HITRAN $2004)$ or changing the UV cross sections by $-5 \%$. The results in Table 6 indicate that these changes in the spectroscopic databases induce low $(0.7 \%$ for HITRAN 2000) and positive (5.7\% with $-5 \%$ UV cross sections) mean biases at the UPTO30 partial column (partially including the stratospheric ozone layer). However, aberrant retrievals are obtained in the troposphere for both corrections. Table 6 shows strong negative biases in the LMT and the LT (between -10 and $-17 \%$ ), higher RMS and much lower linear correlations than in Table 2. Among the tested databases, only HITRAN 2004 and BRION1993 enable a good match between the IASI + GOME-2 approach and ozonesondes (shown in Tables 2 and 3 ).

\section{Lowermost tropospheric ozone observed by IASI + GOME-2}

Fig. 8. Taylor diagrams summarizing normalized standard deviations of the satellite retrievals $|\sigma|$, linear correlation coefficients $R$ and centred RMS differences (CMRS) between ozone measurements from IASI + GOME-2 (red), IASI (green) and GOME-2 (blue) and 105 ozonesondes (smoothed by the retrieval AVK on the left and raw to the right) during summer 2009 over Europe, for the (a and b) LMT, (c and d) LT and (e and f) TROPO partial columns. $|\sigma|$ and CMRS are normalized by the ozonesonde measurements' (smoothed or raw) standard deviations.

RMS differences with respect to raw ozonesondes are generally greater than the estimations of the total retrieval errors $s_{\text {col }}^{\text {tot }}$ (shown in Table 3 for IASI + GOME-2), as they also include errors in the ozonesondes $(\sim 5 \%)$ and ozone variability within the spatio-temporal coincidence criteria (or due to eventual underestimations of $s_{\text {col }}^{\text {tot }}$ ). For the LMT and LT, RMS differences for direct comparisons (2.3 and 4.2 DU respectively, see Table 3) are consistent with the sum of the smoothing error $s_{\text {col }}^{\text {smoth }}$ and the RMS differences with smoothed ozonesondes (see Tables 2 and 3, the root sum of variances are respectively 2.5 and $4.5 \mathrm{DU}$ ). Subtracting the variance from ozonesonde errors, we estimate a precision of the IASI + GOME-2 retrievals in the LMT of $21.4 \%$ for direct comparisons and $16.2 \%$ when smoothing by the retrieval sensitivity.

In this section, we illustrate the capacities of the IASI + GOME-2 multispectral approach to characterize ozone pollution events at the regional scale. We analyse LT and LMT ozone observations for a typical ozone pollution outbreak over Europe during summer. It is a moderate ozone event, mainly occurring on 19 and 20 August 2009 (also analysed by Sellitto et al., 2013, and Foret et al., 2013). Surface ozone concentrations occasionally reached $90 \mathrm{ppb}$ (the ozone information threshold; e.g. EEA, 2011). It occurs during typical summer anticyclonic conditions and relatively high surface temperatures over western Europe (as similarly analysed over southern Europe by Millan et al., 2002).

First, we describe the ozone pollution event as seen by different satellite observations (Sect. 4.1). Then, we compare IASI + GOME-2 observations with the state-of-the-art regional chemistry-transport model CHIMERE (Schmidt et al., 2001; Bond et al., 2007) in Sect. 4.2. Rather than a validation, this comparison verifies the qualitative inter-consistency of IASI+ GOME-2 and CHIMERE for describing the spatial distribution of ozone plumes and it illustrates the potential of IASI + GOME-2 for evaluating air quality models or for data assimilation (e.g. Zyryanov et al, 2012; and Coman et al., 2012). CHIMERE runs with a horizontal resolution 
Table 6. Evaluation of potential effects of spectroscopic incoherencies between the UV and TIR data sets on the multispectral ozone retrieval. The same comparison (105 ozonesondes smoothed by the retrieval AVKs) as in Table 2 is performed, but for 2 test cases: (left) using TIR spectroscopic parameters from HITRAN 2000 or (right) decreasing UV cross sections by $-5 \%$ with respect to BRION1993.

\begin{tabular}{clll}
\hline \multicolumn{5}{c}{ IASI + GOME-2 with HITRAN $2000 /-5 \%$ UV cross } \\
\multicolumn{4}{c}{ sections vs. ozonesondes smoothed by the retrieval AVK } \\
\hline Atmospheric column & Bias & RMS & $R$ \\
LMT & $-1.6 /-1.1$ & $2.6 / 2.3$ & $0.68 / 0.76$ \\
& $-14.2 \% /-10.7 \%$ & $23.9 \% / 21.6 \%$ & \\
LT & $-3.9 /-2.5$ & $5.8 / 4.9$ & $0.36 / 0.56$ \\
& $-17.1 \% /-11.2 \%$ & $25.3 \% / 21.6 \%$ & \\
TROPO & $-3.9 /-3.3$ & $7.8 / 7.1$ & $0.84 / 0.88$ \\
& $-8.0 \% /-7.2 \%$ & $15.9 \% / 15.6 \%$ & \\
UPTO30 & $1.9 / 14.1$ & $12.6 / 19.1$ & $0.96 / 0.95$ \\
& $0.7 \% / 5.7 \%$ & $4.8 \% / 7.7 \%$ & \\
\hline
\end{tabular}

of $0.25^{\circ} \times 0.25^{\circ}$ and 17 vertical levels from the surface up to $200 \mathrm{hPa}$. It is driven by ECMWF meteorological analysis and it uses boundary conditions every $3 \mathrm{~h}$, supplied by the global model MOZART (Model for Ozone and Related chemical Tracers; Horowitz et al., 2003; Emmons et al., 2010). CHIMERE outputs for 19-20 August 2009 have been exhaustively validated against surface and ozonesonde measurements, showing very similar agreement as obtained for previous studies (Zyryanov et al, 2012). For the comparison we use CHIMERE outputs at 10:00 UTC (Universal Time Coordinated).

\subsection{Satellite retrieval of LT ozone}

Figure 9 shows LT ozone retrievals by IASI + GOME-2 (top), IASI (middle) and GOME-2 (bottom) for the 2 days of the ozone pollution event. The main ozone pollution plume over western Europe is consistently observed over land by both IASI and IASI + GOME-2. On 19 August, it is located over Spain (centred at $38^{\circ} \mathrm{N}, 5^{\circ} \mathrm{W}$ ) and France $\left(44-50^{\circ} \mathrm{N}, 0\right.$ $\left.5^{\circ} \mathrm{E}\right)$. The day after, it is observed over Germany and Denmark $\left(49-55^{\circ} \mathrm{N}, 10^{\circ} \mathrm{E}\right)$ following an eastward travelling meteorological front originating from the Atlantic (see the white cloudy band over the United Kingdom, $55^{\circ} \mathrm{N}, 2^{\circ} \mathrm{W}$ ). This ozone plume is not clearly made evident by GOME- 2 only retrievals, as may be expected due to its small sensitivity in the LT (see Table 1). IASI + GOME-2 observations show slightly higher $(3-10 \%)$ ozone concentrations within the plume than detected by IASI. Note that both observations are not directly comparable due to differences in the AVKs. The larger values for IASI + GOME- 2 are consistent with the sensitivity gain in the lowest layers, which enables the observation of higher ozone concentrations produced near the surface.

The multispectral retrieval IASI + GOME-2 (Fig. 9a, b) shows additional LT ozone plumes both over land and over ocean, which are not clearly depicted by the single-band approaches (Fig. 9c-f). Over ocean, this is the case over the
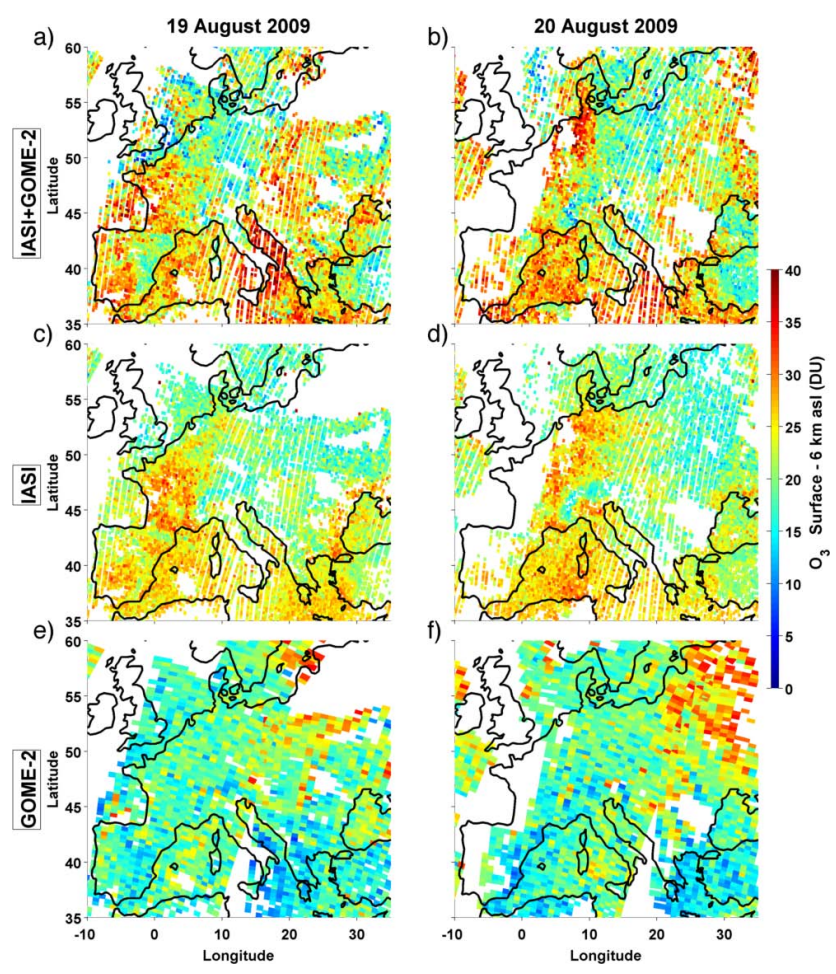

Fig. 9. Ozone observations (DU) in the lower troposphere partial column (LT, up to $6 \mathrm{~km}$ a.s.1.) over Europe on 19 (left) and 20 (right) August 2009 from (a and b) IASI + GOME-2, (c and d) IASI only and (e and f) GOME-2 only approaches.

Mediterranean (Fig. 9a, particularly northeast of Italy, $42^{\circ} \mathrm{N}$ $\left.3^{\circ} \mathrm{E}\right)$, over the Atlantic $\left(45^{\circ} \mathrm{N}, 3^{\circ} \mathrm{W}\right)$, over the North Sea $\left(55^{\circ} \mathrm{N}, 3^{\circ} \mathrm{E}\right)$ and over the Black Sea $\left(45^{\circ} \mathrm{N}, 30^{\circ} \mathrm{E}\right)$. This retrieval also enables the observation of continuous structures of high ozone concentrations between ocean and land (e.g. on 19 August over the Atlantic, the North Sea and the Black Sea). Over land, only IASI + GOME-2 clearly depicts an ozone plume over eastern Europe (e.g. Fig. 9a, over 


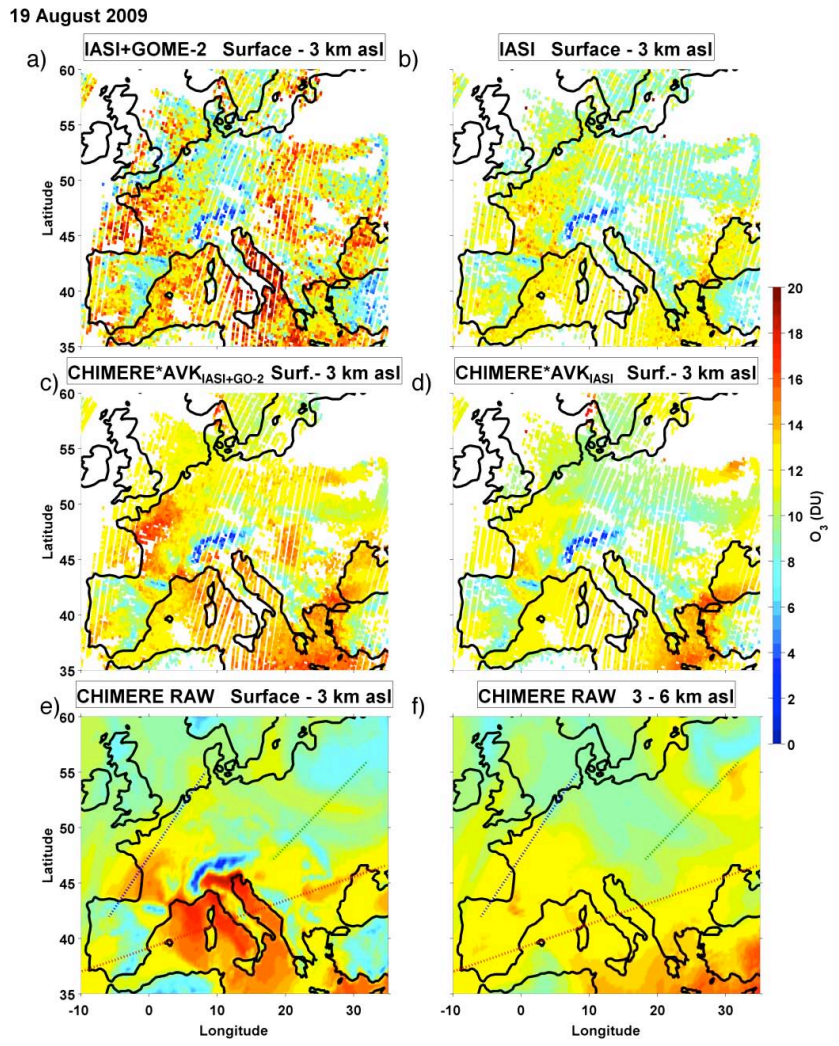

Fig. 10. Ozone observations (DU) in the lowermost troposphere (LMT, up to $3 \mathrm{~km}$ a.s.1.) from (a) IASI + GOME-2 and (b) IASI only over Europe on 19 August 2009. CHIMERE model outputs in the LMT (up to $3 \mathrm{~km}$ a.s.1.) smoothed by the AVKs of (c) IASI + GOME-2 and (d) IASI only. CHIMERE raw outputs (e) in the LMT and (f) integrated between 3 and $6 \mathrm{~km}$ a.s.1. (e and f). The dashed lines indicate the location of the northwestern (blue), northeastern (green) and southern (red) transects in Fig. 12.

Poland, Hungary and Romania, $\left.45-52^{\circ} \mathrm{N}, 20-30^{\circ} \mathrm{E}\right)$. It is consistently seen on both days (moving eastwards) and for 2 successive MetOp-A overpasses on each day. Over Hungary $\left(47^{\circ} \mathrm{N}, 22^{\circ} \mathrm{E}\right)$, IASI retrievals show a weak concentration increase within the background variability and less marked than the western plume over Spain and France (Fig. 9c, d). GOME-2 retrievals suggest high ozone concentrations for the northeastern part of the plume $\left(50^{\circ} \mathrm{N}, 20-35^{\circ} \mathrm{E}\right.$ in Fig. $9 \mathrm{e}$ and f), where LT sensitivity is likely enhanced by the presence of sparse low-level clouds (see Fig. 2d).

\subsection{Comparison of IASI + GOME-2 with simulated LMT ozone}

Figures 10 and 11 present a comparison of IASI + GOME2 (Figs. 10a, 11a) and IASI only (Figs. 10b, 11b) ozone observations in the LMT (up to $3 \mathrm{~km}$ a.s.1.) with the corresponding CHIMERE outputs (smoothed by the AVKs of each satellite retrieval in Figs. 10c and d, and 11c and d). A remarkable overall agreement in the ozone plume struc-

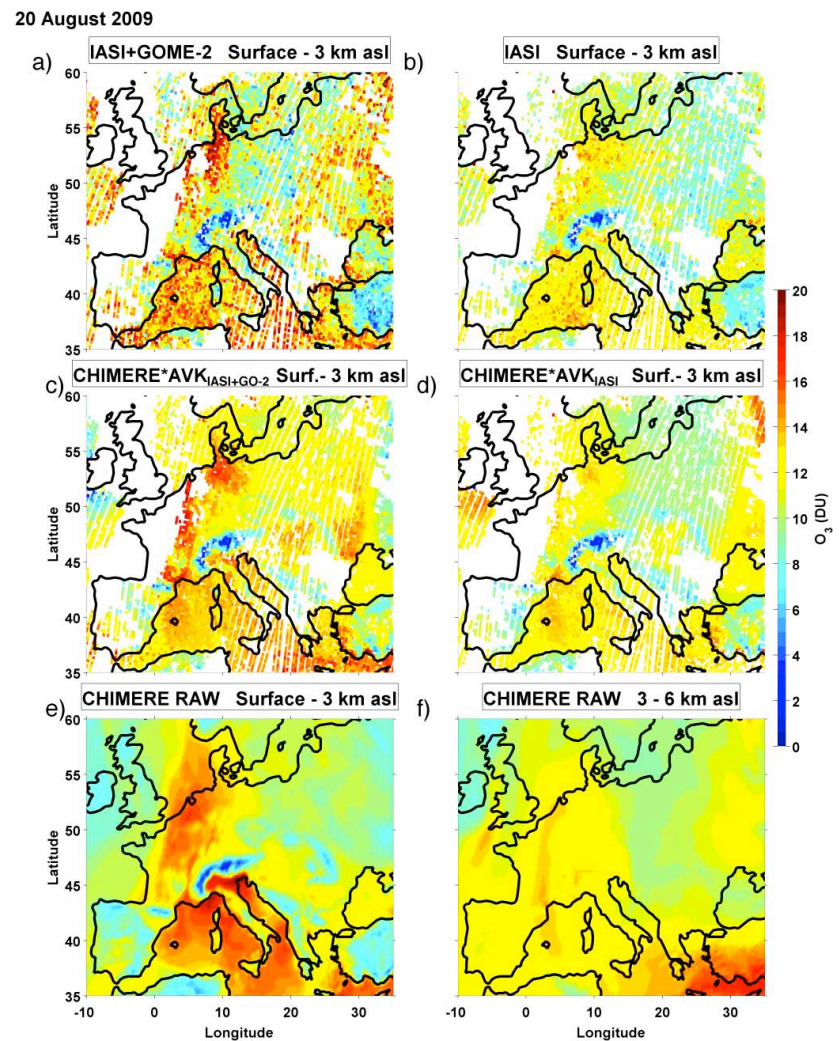

Fig. 11. Same as Fig. 10, but for 20 August 2009.

tures is observed for the 2 days of the pollution event between the satellite observations and the smoothed model outputs, both for IASI + GOME-2 and IASI only. On 19 August, the western plumes over land (over France and Spain) are clearly depicted with very similar structures in the observed and simulated LMT ozone columns, both for IASI + GOME-2 and IASI. A particularly good agreement is seen for the shape of the ozone plumes on the west and southwest of France and west of Spain (Fig. 10a-d). Note that lower concentrations at the edges of the plumes may also result from thinner partial columns over mountains (e.g. east of Spain, the Alps or the Pyrenees; also apparent in the DOF $_{\text {LMT }}$ distribution in Fig. 6a). According to CHIMERE outputs without smoothing (Fig. 10e and the vertical transect in Fig. $12 \mathrm{a}$ at $44-49^{\circ} \mathrm{N}$ ), high ozone concentrations

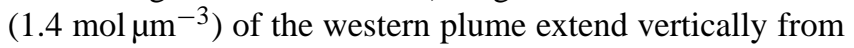
the top of the atmospheric mixing layer (at $1-1.5 \mathrm{~km}$ a.g.1. over land) up to $3.5-4 \mathrm{~km}$ a.s.1. Moderate concentrations

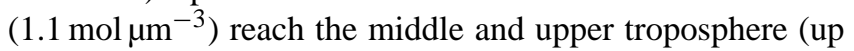
to $8-9 \mathrm{~km}$ a.s.1.). Over land $\left(46-49^{\circ} \mathrm{N}\right)$, this plume is observed by both retrievals as $H_{\mathrm{LMT}}^{\max }$ is located below $4 \mathrm{~km}$ a.s.l. for the 2 cases. Over ocean $\left(44-46^{\circ} \mathrm{N}\right)$, only IASI + GOME2 (with $H_{\mathrm{LMT}}^{\max }$ below $4 \mathrm{~km}$ a.s.l.) depicts this plume, as IASI is sensitive at $5 \mathrm{~km}$ a.s.l. at lowest. Similar situations are remarked for the ozone plumes over the Mediterranean and the Black Sea. Also there, high ozone concentrations only 

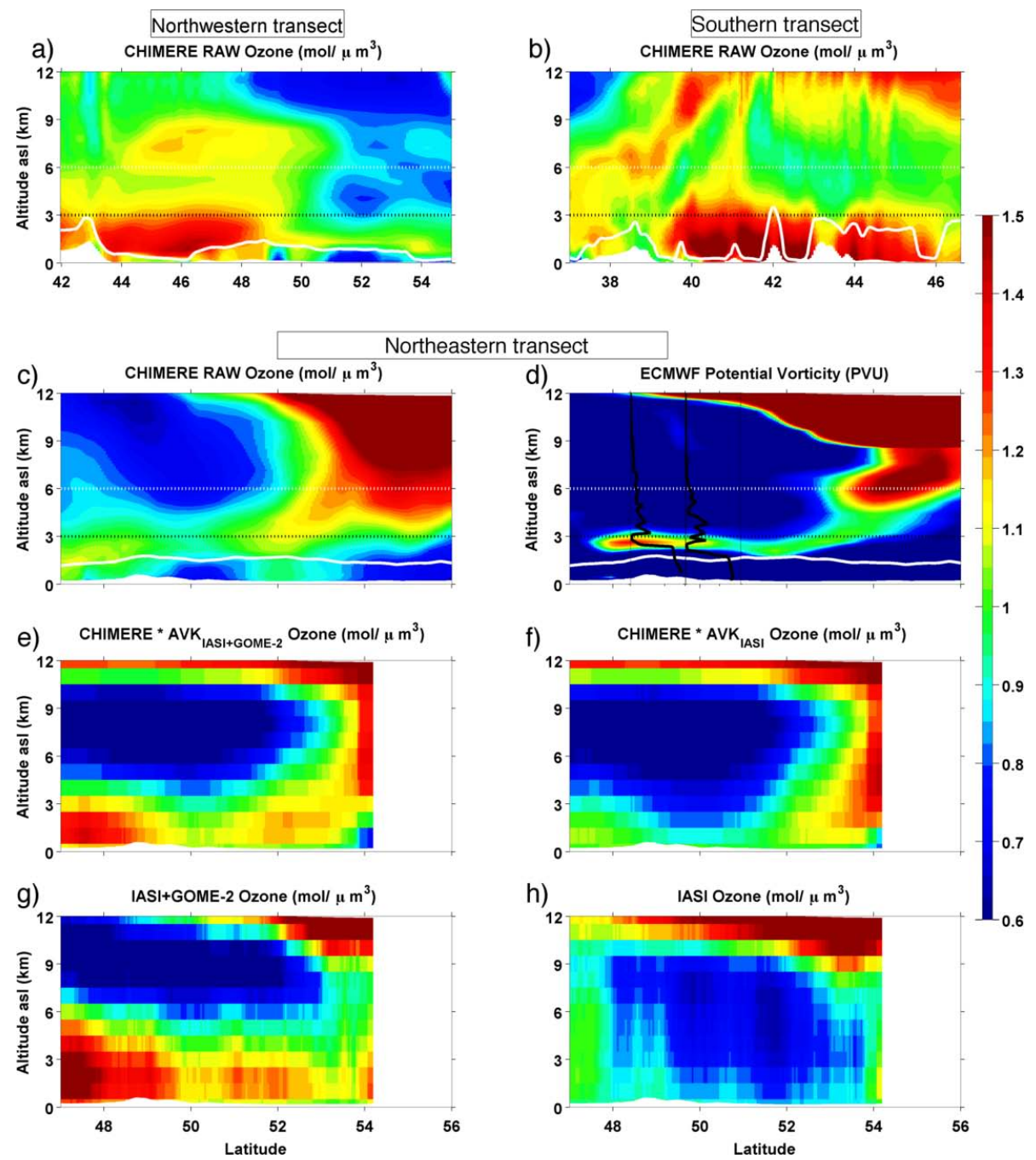

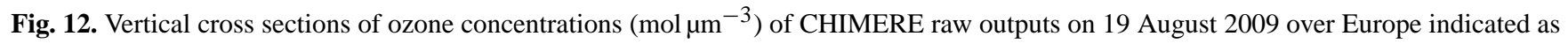
dashed lines in Fig. 10e and f as (a) northwestern, (b) southern and (c) northeastern transects. Plain white lines are atmospheric mixing layer heights derived from ECMWF. Northeastern transects of (d) ECMWF potential vorticity (in PV units, with 2 profiles of specific humidity between 0 and $8 \mathrm{~g} \mathrm{~kg}^{-1}$ from co-localized radiosoundings from http://weather.uwyo.edu/upperair/sounding.html); CHIMERE ozone outputs smoothed by the AVKs of (e) IASI + GOME-2 and (f) IASI; and satellite observations from (g) IASI + GOME-2 and (h) IASI. Dotted black (white) lines indicate $3 \mathrm{~km}$ a.s.1.(6 km a.s.1.).

observed by IASI + GOME-2 (with $H_{\mathrm{LMT}}^{\max }$ of $\sim 3.1 \mathrm{~km}$ a.g.1.) are consistently simulated by CHIMERE extending up to $3-$ $4 \mathrm{~km}$ a.s.l. (see Figs. 10e and 12b). The unique capacity of IASI + GOME-2 to detect these plumes over ocean is consistently remarked by the differences between CHIMERE smoothed by the AVKs of the 2 retrievals (Fig. 10c, d). Moreover, IASI + GOME-2 is also capable of depicting the ozone plume over the North Sea (Fig. 10a, at $55^{\circ} \mathrm{N}, 7^{\circ} \mathrm{E}$ ), where CHIMERE simulates moderate ozone concentrations only extending vertically up to $2.5 \mathrm{~km}$ a.s.l. (see Fig. 12a at 54 $55^{\circ} \mathrm{N}$ ). Additionally, both IASI + GOME-2 and CHIMERE consistently show the ocean-land continuity of the plumes over the Atlantic, the Black Sea and the North Sea (Fig. 10a, c, e). Interestingly, also large sea-land gradients between the
Adriatic Sea and Italy as well as the western Mediterranean and Spain appear both in IASI + GOME-2 LMT observations and in smoothed CHIMERE simulations. Theses differences are both due to larger LMT ozone concentrations over the sea and to greater sensitivities over land than over the sea.

The eastern ozone plumes over land (over Poland, Hungary and Romania on 19 August) are only clearly depicted by IASI + GOME-2 LMT observations and CHIMERE outputs (both raw and smoothed by the multispectral AVKs, see Fig. 10a, c and e). According to CHIMERE transects, the plumes over Hungary (at $47-50^{\circ} \mathrm{N}$ in Fig. 12c) and Romania (at $44-46^{\circ} \mathrm{N}$ in Fig. 12b) are mainly located at the LMT (up to $\sim 3 \mathrm{~km}$ a.s.l.), respectively above and within the atmospheric mixing layer. This is consistent with the 
fact that these plumes are clearly made evident only by IASI + GOME-2 (with $H_{\mathrm{LMT}}^{\mathrm{max}}$ of $\sim 1.9 \mathrm{~km}$ a.g.l.), whereas IASI only ( $H_{\mathrm{LMT}}^{\mathrm{max}}$ of $\sim 2.9 \mathrm{~km}$ a.g.l.) observes slightly higher concentrations (within the background variability and noise). These plumes are more apparent in noiseless CHIMERE outputs smoothed by IASI sensitivity (Fig. 10d) than in IASI's real observations (Fig. 10b). Otherwise, a different situation is remarked for the ozone plume over Poland (50$52^{\circ} \mathrm{N}, 19-33^{\circ} \mathrm{E}$ in Fig. 10a). This ozone layer is clearly shown by IASI + GOME- 2 and CHIMERE at the LMT (raw and smoothed simulations in Figs. 10e, 12c and e), but it is clearly absent from IASI observations (Figs. 10b, 12h) and CHIMERE smoothed by IASI AVKs (Figs. 10f, 12f). According to transects of CHIMERE's raw outputs and ECMWF's potential vorticity (Fig. 12c-d), this plume is a rather thin filament of ozone located between 2 and $4 \mathrm{~km}$ a.s.1. (at $50-52^{\circ} \mathrm{N}$ ), which originates from an intrusion of lower stratospheric air further north (at $53-56^{\circ} \mathrm{N}$ ). As expected for stratospheric air, very low humidity is observed at the altitudes of this ozone filament (see radiosounding profiles at 2-3 km a.s.l. in Fig. 12d). Above this ozone-enriched layer, very low ozone concentrations extend up to $12 \mathrm{~km}$ a.s.l. (Fig. 12c). Figure 12g shows that IASI + GOME-2 is capable of resolving this complex vertical distribution of ozone (particularly at $50-52^{\circ} \mathrm{N}$ ), showing higher concentrations at the LMT (i.e. the ozone filament) below a very clean upper troposphere, as also qualitatively depicted by raw CHIMERE outputs (see Fig. 12c). The vertical structures and ozone concentrations depicted by IASI + GOME-2 observations match fairly well those shown by CHIMERE simulations smoothed by the multispectral AVKs (Fig. 12e). The descending part of the ozone filament is also apparent at $53-54^{\circ} \mathrm{N}$ both in IASI + GOME-2 observations (Fig. 12g) and CHIMERE outputs (Fig. 12c, e). On the contrary, IASI mainly detects low ozone concentrations in the free troposphere and is unable to resolve the ozone plume at the LMT (see Fig. 12h at 50$52^{\circ} \mathrm{N}$ ). This is also shown by CHIMERE outputs smoothed by IASI AVKs (Fig. 12f), suggesting that it is mainly linked to the coarser vertical resolution and lower sensitivity of IASI with respect to IASI + GOME-2. On the other hand, GOME2 retrievals show enhanced ozone concentrations over Poland (at $50-52^{\circ} \mathrm{N}$, see Fig. 9e), but extending over the whole troposphere (not shown) as expected by limited $\mathrm{DOF}_{\mathrm{TROPO}}$ with respect to IASI + GOME-2.

On 20 August, ozone plumes shift eastwards (Fig. 11). Both CHIMERE simulations and IASI + GOME-2 observations show higher ozone concentrations below $3 \mathrm{~km}$ a.s.l. at the centre of the western ozone plume over northern Ger-

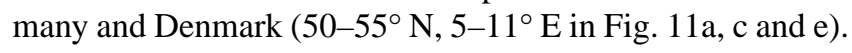
In Fig. 11b, IASI depicts the western plume extending further east (until $15^{\circ} \mathrm{E}$ ) with similar concentrations as over and south of Denmark, as similarly remarked in CHIMERE's raw outputs between 3 and $6 \mathrm{~km}$ a.s.l. (Fig. 11f). As on $19 \mathrm{Au}-$ gust, the eastern plumes $\left(45-60^{\circ} \mathrm{N}, 20-35^{\circ} \mathrm{E}\right)$ are only seen in IASI + GOME-2 observations and CHIMERE simulations (smoothed by the multispectral AVKs and raw outputs from 3 to $6 \mathrm{~km}$ a.s.l. and suggested at the LMT, see Fig. 11c, e and f), but not by IASI.

In terms of absolute ozone concentrations, IASI + GOME2 (Figs. 10a, 11a) and CHIMERE outputs smoothed by IASI + GOME-2 sensitivity (Figs. 10c, 11c) show a general good agreement (mean bias below $1 \%$ over the whole region). Some differences in the background concentrations (around 1-2 DU) are observed locally, as expected by the uncertainties in both data. In general, IASI + GOME-2 ozone columns show more horizontal variability, which could be linked to retrieval noise ( $s_{\mathrm{LMT}}^{\text {tot }}$ is $\sim 2 \mathrm{DU}$ ) or also possibly to smoothed model outputs.

According to CHIMERE's raw outputs (Figs. 10f, 11f), the ozone plumes reaching altitudes above $3 \mathrm{~km}$ a.s.l. (i.e. the western ozone plume in Fig. 9) correspond to the ones clearly observed over land by both IASI and IASI + GOME-2. Since $\mathrm{DOF}_{\mathrm{LMT}}$ for IASI + GOME-2 is lower than 1, multispectral outputs in the LMT (Figs. 10a, 11a) are expected to depend as well on ozone concentrations up to 5 or $6 \mathrm{~km}$ a.s.l. (see AVKs over land in Fig. 4). Thus, IASI + GOME-2 retrievals alone cannot tell whether the ozone plumes are located in the LMT or between 3 and $6 \mathrm{~km}$ a.s.l. However, one may identify ozone plumes located below $3 \mathrm{~km}$ a.s.l. as they are clearly depicted by IASI + GOME-2, but not by IASI.

\section{Summary and perspectives}

We have presented a new multispectral approach, IASI+GOME-2, to observe ozone in the lowermost troposphere, by combining the information provided by IASI (TIR) and GOME-2 (UV) spaceborne observations. The information content enhancement for IASI + GOME-2 enables an increase of sensitivity to ozone in the whole atmospheric column, especially below $3 \mathrm{~km}$ a.s.l. (LMT, which is particularly valuable for ozone pollution studies) and at the UTLS. Sensitivity in the LMT shows a relative maximum peaking on average at $2.2 \mathrm{~km}$ a.g.l. over land (thus at least $800 \mathrm{~m}$ below than the single-band methods). The multispectral enhancement of $\mathrm{DOF}_{\mathrm{LMT}}$ is at least of 0.1 , thus at least $40 \%$ higher than single-band retrievals in relative terms. Validation against ozonesondes (over Europe during summer 2009) shows very low mean biases (below $1 \%)$ and relatively good linear correlations (0.84 and 0.76$)$ for the tropospheric columns up to 3 and $6 \mathrm{~km}$ a.s.l. (LMT and LT). Only IASI+GOME-2 observations at the LMT present similar variability with respect to the ozonesonde measurements (both raw and smoothed by the multispectral AVK), while keeping similar linear correlations and precision as the single-band retrievals (which underestimate the concentrations and the standard deviation of ozonesonde observations). In the case study of Sect. 4, ozone plumes reaching altitudes above $3 \mathrm{~km}$ a.s.l. (according to CHIMERE model simulations) are consistently depicted over land by 
both IASI + GOME-2 and IASI only. The unique capacity of IASI + GOME-2 is the clear observation of ozone plumes located below $3 \mathrm{~km}$ a.s.l. (LMT) both over land and over ocean. This is a major step forward in spaceborne remote sensing of lowermost tropospheric ozone and its application for air quality studies.

A further improvement for detection of near-surface ozone is expected by including the information provided by the Chappuis band in the visible (VIS) spectrum (Chance et al., 1997). The advantages of a combined UV + VIS retrieval of ozone have been experimentally confirmed with real satellite observations by a neural network approach (Sellitto et al., 2012a, b). Future works for further improvement of the IASI + GOME-2 approach will focus on a three-band multispectral retrieval; i.e. UV + VIS + TIR.

Acknowledgements. The authors are grateful for the financial support given by the Centre National des Etudes Spatiales (CNES, the French Space Agency), the Université Paris Est Créteil (UPEC) and the Centre National des Recherches Scientifiques - Institut National des Sciences de l'Univers (CNRS-INSU) for achieving this research work and its publication. This study was supported by the project "GEOQAIR-TOSCA" (Terre, Océan, Surfaces continentals, Atmosphère) financed by CNES and by a "Chaire d'Excellence" of UPEC and CNES. IASI is a joint mission of EUMETSAT and CNES. We acknowledge the support by the data centres ETHER (http://www.pole-ether.fr/) and NOAA CLASS (http://www.class.ncdc.noaa.gov) for providing respectively L1 IASI and GOME-2 data sets, which are originally supplied by EUMETSAT through the Eumetcast system distribution (http://www.eumetsat.int). Meteorological analyses are supplied by ECMWF, surface emissivities by the University of Wisconsin, MODIS-derived aerosol optical depth by NASA and radiosounding profiles by the University of Wyoming. The ozonesonde data sets used in this study were provided by WOUDC. We acknowledge groups responsible for the WOUDC measurements and archives for making the ozonesonde data available. We thank the organizers of the POGEQA meetings in Toulouse and Emeric Hache from Meteo-France for collaboration on radiative transfer calculations as well as Benedict Picquet-Varrault, Aline Gratien, Agnes Perrin and Jean-Michel Hartmann from LISA for fruitful discussions on ozone spectroscopy.

Edited by: M. Van Roozendael

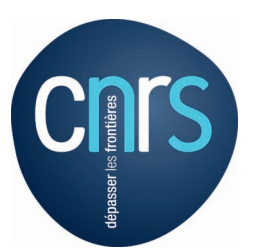

The publication of this article is financed by CNRS-INSU.

\section{References}

Bhartia, P. K. and Wellemeyer, C. W.: TOMS-V8 total O3 algorithm, OMI Algorithm Theoretical Basis Document 2, 15-31, 2002.
Brion, J., Chakir, A., Daumont, D., Malicet, J., and Parisse, C.: High-resolution laboratory absorption cross section of $\mathrm{O}_{3}$ : Temperature effect, Chem. Phys. Lett., 213, 610-612, doi:10.1016/0009-2614(93)89169-I, 1993.

Cai, Z., Liu, Y., Liu, X., Chance, K., Nowlan, C. R., Lang, R., Munro, R., and Suleiman, R.: Characterization and correction of Global Ozone Monitoring Experiment 2 ultraviolet measurements and application to ozone profile retrievals?, J. Geophys. Res., 117, D07305, doi:10.1029/2011JD017096, 2012.

Chance, K. V., Burrows, J. P., Perner, D., and Scheider, W.: Satellite measurements of atmospheric ozone profiles, including tropospheric ozone, from ultraviolet/visible measurements in the nadir geometry: a potential method, J. Quant. Spectrosc. Ra., 57, 467476, doi:10.1016/S0022-4073(96)00157-4, 1997.

Chance, K., and R. L. Kurucz: An improved high-resolution solar reference spectrum for Earth's atmosphere measurements in the ultraviolet, visible, and near infrared, J. Quant. Spectrosc. Radiat. Transf., 111, 1289-1295, doi:10.1016/j.jqsrt.2010.01.036, 2010.

Clerbaux, C., Boynard, A., Clarisse, L., George, M., Hadji-Lazaro, J., Herbin, H., Hurtmans, D., Pommier, M., Razavi, A., Turquety, S., Wespes, C., and Coheur, P.-F.: Monitoring of atmospheric composition using the thermal infrared IASI/MetOp sounder, Atmos. Chem. Phys., 9, 6041-6054, doi:10.5194/acp-9-6041-2009, 2009.

Coheur, P. F., Barret, B., Turquety, S., Hurtmans, D., Hadji-Lazaro, J., and Clerbaux, C.: Retrieval and characterization of ozone vertical profiles from a thermal infrared nadir sounder, J. Geophys. Res., 110, D24303, doi:10.1029/2005JD005845, 2005.

Coman, A., Foret, G., Beekmann, M., Eremenko, M., Dufour, G., Gaubert, B., Ung, A., Schmechtig, C., Flaud, J.-M., and Bergametti, G.: Assimilation of IASI partial tropospheric columns with an Ensemble Kalman Filter over Europe, Atmos. Chem. Phys., 12, 2513-2532, doi:10.5194/acp-12-2513-2012, 2012.

Crutzen, P. J., Lawrence, M. G., and Pöschl, U.: On the background photochemistry of tropospheric ozone, Tellus B, 51, 123-146, 1999.

Deshler, T., Mercer, J. L., Smit, H. G. J., Stubi, R., Levrat, G., Johnson, B. J., Oltmans, S. J., Kivi, R., Thompson, A M., Witte, J., Davies, J., Schmidlin, F. J., Brothers, G., and Sasaki, T.: Atmospheric comparison of electrochemical cell ozonesondes from different manufacturers, and with different cathode solution strengths: The Balloon Experiment on Standards for Ozonesondes, J. Geophys. Res., 113, D04307, doi:10.1029/2007JD008975, 2008.

Dufour, G., Eremenko, M., Orphal, J., and Flaud, J.-M.: IASI observations of seasonal and day-to-day variations of tropospheric ozone over three highly populated areas of China: Beijing, Shanghai, and Hong Kong, Atmos. Chem. Phys., 10, $3787-$ 3801, doi:10.5194/acp-10-3787-2010, 2010.

Dufour, G., Eremenko, M., Griesfeller, A., Barret, B., LeFlochmoën, E., Clerbaux, C., Hadji-Lazaro, J., Coheur, P.-F., and Hurtmans, D.: Validation of three different scientific ozone products retrieved from IASI spectra using ozonesondes, Atmos. Meas. Tech., 5, 611-630, doi:10.5194/amt-5-611-2012, 2012.

Emmons, L. K., Walters, S., Hess, P. G., Lamarque, J.-F., Pfister, G. G., Fillmore, D., Granier, C., Guenther, A., Kinnison, D., Laepple, T., Orlando, J., Tie, X., Tyndall, G., Wiedinmyer, C., Baughcum, S. L., and Kloster, S.: Description and evaluation of 
the Model for Ozone and Related chemical Tracers, version 4 (MOZART-4), Geosci. Model Dev., 3, 43-67, doi:10.5194/gmd3-43-2010, 2010.

Eremenko, M., Dufour, G., Foret, G., Keim, C., Orphal, J., Beekmann, M., Bergametti, G., and Flaud, J.-M.: Tropospheric ozone distributions over Europe during the heat wave in July 2007 observed from infrared nadir spectra recorded by IASI, Geophys. Res. Lett., 35, L18805, doi:10.1029/2008GL034803, 2008.

European Environment Agency: Air quality in Europe - 2011 report. EEA Technical report 12/2011, Publications Office of the European Union, ISSN 1725-2237, doi:10.2800/83213, 2011.

European Organisation for the Exploitation of Meteorological Satellites (EUMETSAT): GOME-2 Level 1 product generation specification, EPS.SYS.SPE.990011, Darmstadt, Germany, 2006.

Fishman, J., Iraci, L. T., Al-Saadi, J., Chance, K., Chavez, F., Chin, M., Coble, P., Davis, C., DiGiacomo, P. M., Edwards, D., Eldering, A., Goes, J., Herman, J., Hu, C., Jacob, D. J., Jordan, C., Kawa, S. R., Key, R., Liu, X., Lohrenz, S., Mannino, A., Natraj, V., Neil, D., Neu, J., Newchurch, M., Pickering, K., Salisbury, J., Sosik, H., Subramaniam, A., Tzortziou, M., Wang, J., and Wang, M.: The United States' next generation of atmospheric composition and coastal ecosystem measurements: NASA's Geostationary Coastal and Air Pollution Events (Geo-Cape) Mission, B. Am. Meteorol. Soc., 93, 1547-1566, 2012.

Foret, G., Eremenko, M., Cuesta, J., Sellitto, P., Barré, J., Gaubert, B., Coman, A., Dauphin, P., Beekmann, M., and Dufour, G.: Ozone pollution : What do we see from space?, A case study, 3rd Conference IASI, Hyères, France, 4-8 February 2013.

Fu, D., Worden, J. R., Liu, X., Kulawik, S. S., Bowman, K. W., and Natraj, V.: Characterization of ozone profiles derived from Aura TES and OMI Radiances. Atmos. Chem. Phys., 13, 34453462, doi:10.5194/acp-13-3445-2013, 2013.

Fuhrer, J.: Ozone risk for crops and pastures in present and future climates, Naturwissenschaften, 96, 173-194, 2009.

Fuhrer, J. and Achermann, B.: Critical Levels for Ozone: A UNECE Workshop Report., in: Critical Levels for Ozone: A UNECE Workshop Report, Liebefeld-Bern, Switzerland, No. 16, 1994.

Gratien, A., Picquet-Varrault, B., Orphal, J., Doussin, J.-F., and Flaud, J.-M.: New Laboratory Intercomparison of the Ozone Absorption Coefficients in the Mid-infrared $(10 \mu \mathrm{m})$ and Ultraviolet (300-350 nm) Spectral Regions, J. Phys. Chem. A, 114, 1004510048, 2010.

Gryparis, A., Forsberg, B., Katsouyanni, K., Analitis, A., Touloumi, G., Schwartz, J., Samoli, E., Medina, S., Anderson, H. R., Niciu, E. M., Wichmann, H. E., Kriz, B., Kosnik, M., Skorkovsky, J., Vonk, J. M., and Dortbudak, Z.: Acute effects of ozone on mortality from the "Air pollution and health: A European approach" project, Am. J. Respir. Crit. Care Med., 170, 1080-1087, doi:10.1164/rccm.200403-333OC, 2004.

Hollaway, M. J., Arnold, S. R., Challinor, A. J., and Emberson, L. D.: Intercontinental trans-boundary contributions to ozoneinduced crop yield losses in the Northern Hemisphere, Biogeosciences, 9, 271-292, doi:10.5194/bg-9-271-2012, 2012.

Horowitz, L. W., Walters, S., Mauzerall, D. L., Emmons, L. K., Rasch, P. J., Granier, C., Tie, X., Lamarque, J.-F., Schultz, M. G., Tyndall, G. S., Orlando, J. J., and Brasseur, G. P.: A global simulation of tropospheric ozone and related tracers: Description and evaluation of MOZART, version 2, J. Geophys. Res., 108, 4784, doi:10.1029/2002JD002853, 2003.

Ito, K., De Leon, S. F., and Lippmann, M.: Associations between ozone and daily mortality - Analysis and meta-analysis, Epidemiology, 16, 446-457, 2005.

Keim, C., Eremenko, M., Orphal, J., Dufour, G., Flaud, J.-M., Höpfner, M., Boynard, A., Clerbaux, C., Payan, S., Coheur, P.- F., Hurtmans, D., Claude, H., Dier, H., Johnson, B., Kelder, H., Kivi, R., Koide, T., Lopez Bartolome, M., Lambkin, K., Moore, D., Schmidlin, F. J., and Stübi, R.: Tropospheric ozone from IASI: comparison of different inversion algorithms and validation with ozone sondes in the northern middle latitudes, Atmos. Chem. Phys., 9, 9329-9347, doi:10.5194/acp-9-9329-2009, 2009.

Kleipool, Q. L., Dobber, M. R., de Haan, J. F., and Levelt, P. F.: Earth surface reflectance climatology from 3 years of OMI data, J. Geophys. Res., 113, D18308, doi:10.1029/2008JD010290, 2008.

Kobayashi, H., Shimota, A., Kondo, K., Okumura, E., Kameda, Y., Shimoda, H. and Ogawa, T.: Development and evaluation of the interferometric monitor for greenhouse gases: A high-throughput Fourier-transform infrared radiometer for nadir Earth observation, Appl. Opt., 38, 6801-6807, 1999.

Koelemeijer, R., Stammes, P., Hovenier, J., and Haan, J. D.: A fast method for retrieval of cloud parameters using oxygen A band measurements from the Global Ozone Monitoring Experiment, J. Geophys. Res., 106, 3475-3490, doi:10.1029/2000JD900657, 2001.

Kulawik, S. S., Osterman, G., Jones, D. B. A., and Bowman, K. W.: Calculation of altitude-dependent Tikhonov constraints for TES nadir retrievals, IEEE Trans. Geosci. Remote Sens., 44, 1334 1342, 2006.

Landgraf, J. and Hasekamp, O. P.: Retrieval of tropospheric ozone: The synergistic use of thermal infrared emission and ultraviolet reflectivity measurements from space, J. Geophys. Res., 112, D08310, doi:10.1029/2006JD008097, 2007.

Levelt, P. F., van den Oord, G. H. J., Dobber, M. R., Mälkki, A., Visser, H., de Vries, J., Stammes, P., Lundell, J., and Saari, H.: The Ozone Monitoring Instrument, IEEE Trans. Geosci. Remote Sens., 44, 1093-1101, 2006.

Liu, X., Bhartia, P. K., Chance, K., Spurr, R. J. D., and Kurosu, T. P.: Ozone profile retrievals from the Ozone Monitoring Instrument, Atmos. Chem. Phys., 10, 2521-2537, doi:10.5194/acp-10-25212010, 2010.

McPeters, R. D., Labow, G. J., and Logan, J. A.: Ozone climatological profiles for satellite retrieval algorithms, J. Geophys. Res., 112, D05308, doi:10.1029/2005JD006823, 2007.

Millan, M. M., Sanz, M. J., Salvador, R., and Mantilla, E.: Atmospheric dynamics and ozone cycles related to nitrogen deposition in the western Mediterranean, Environ. Pollut., 118, 167-186, doi:10.1016/s0269-7491(01)00311-6, 2002.

Natraj, V., Liu, X., Kulawik, S., Chance, K., Chatfield, R., Edwards, D. P., Eldering, A., Francis, G., Kurosu, T., Pickering, K., Spurr, R., and Worden, H.: Multispectral sensitivity studies for the retrieval of tropospheric and lowermost tropospheric ozone from simulated clear sky GEO-CAPE measurements. Atmos. Environ., 45, 7151-7165, doi:10.1016/j.atmosenv.2011.09.014, 2011.

Nowlan, C. R., Liu, X., Chance, K., Cai, Z., Kurosu, T. P., Lee, C., and Martin, R. V.: Retrievals of sulfur dioxide from the Global Ozone Monitoring Experiment 2 (GOME-2) using an optimal es- 
timation approach: Algorithm and initial validation, J. Geophys. Res., 116, D18301, doi:10.1029/2011JD015808, 2011.

Picquet-Varrault, B., Orphal, J., Doussin, J.-F., Carlier, P., and Flaud, J.-M.: Laboratory intercomparison of the ozone absorption coefficients in the mid-infrared $(10 \mu \mathrm{m})$ and ultraviolet $(300$ $350 \mathrm{~nm}$ ) spectral regions, J. Phys. Chem. A., 109, 1008-1014, doi:10.1021/jp0405411, 2005.

Rodgers, C. D.: Inverse methods for atmospheric sounding: Theory and practice, World Scientific Publishing Company, London, UK, 200 pp., 2000.

Rothman, L. S., Jacquemart, D., Barbe, A., Chris Benner, D., Birk, M., Brown, L. R., Carleer, M. R., Chackerian Jr., C., Chance, K., Coudert, L. H., Dana, V., Devi, V. M., Flaud, J.-M., Gamache, R. R., Goldman, A., Hartmann, J.-M., Jucks, K. W., Maki, A. G., Mandin, J.-Y., Massie, S. T., Orphal, J., Perrin, A., Rinsland, C. P., Smith, M. A. H., Tennyson, J., Tolchenov, R. N., Toth, R. A., Vander Auwera, J., Varanasi, P., and Wagner, G.: The HITRAN 2004 molecular spectroscopic database, J. Quant. Spectrosc. Ra., 96, 139-204, 2005.

Schmidt, H., Derognat, C., Vautard, R., and Beekmann, M.: A comparison of simulated and observed ozone mixing ratios for summer of 1998 in western Europe, Atmos. Environ., 35, 6277-6297, 2001

Seemann, S. W., Borbas, E. E., Knuteson, R. O., Stephenson, G. R., and Huang, H.-L.: Development of a Global Infrared Land Surface Emissivity Database for Application to Clear Sky Sounding Retrievals from Multi-spectral Satellite Radiance Measurements. J. Appl. Meteor. Climatol., 47, 108-123, 2007.

Seinfeld, J. H. and Pandis, S. N.: Atmos. Chem. Phys., from Air Pollution to Climate Change, John Wiley \& Sons Inc., Toronto, Canada, 792 pp., 1997.

Sellitto, P., Del Frate, F., Solimini, D., and Casadio, S.: Tropospheric ozone column retrieval from ESA-Envisat SCIAMACHY nadir UV/VIS radiance measurements by means of a neural network algorithm, IEEE Trans. Geosci. Remote Sens., 50, 998-1011, doi:10.1109/TGRS.2011.2163198, 2012a.

Sellitto, P., Di Noia, A., Del Frate, F., Burini, A., Casadio, S., and Solimini, D.: On the role of visible radiation in ozone profile retrieval from nadir UV/VIS satellite measurements: An experiment with neural network algorithms inverting SCIAMACHY data, J. Quant. Spectrosc. Radiat. Trans., 113, 14291436, doi:10.1016/j.jqsrt.2012.04.007, 2012b.

Sellitto, P., Dufour, G., Eremenko, M., Cuesta, J., Dauphin, P., Forêt, G., Gaubert, B., Beekmann, M., Peuch, V.-H., and Flaud, J.-M.: Analysis of the potential of one possible instrumental configuration of the next generation of IASI instruments to monitor lower tropospheric ozone, Atmos. Meas. Tech., 6, 621-635, doi:10.5194/amt-6-621-2013, 2013.

Sioris, C. and Evans, W.: Impact of rotational Raman scattering in the $\mathrm{O}_{2}$ A band, Geophys. Res. Lett., 27, 4085-4088, doi:10.1029/2000GL012231, 2000.

Spurr, R. J. D.: VLIDORT: A linearized pseudo-spherical vector discrete ordinate radiative transfer code for forward model and retrieval studies in multilayer multiple scattering media, J. Quant. Spectrosc. Radiat. Trans., 102, 316-342, doi:10.1016/j.jqsrt.2006.05.005, 2006.

Steck, T.: Methods for determining regularization for atmospheric retrieval problems, Appl. Optics, 41, 1788-1797, doi:10.1364/AO.41.001788, 2002.
Steck, T. and von Clarmann, T.: Constrained Profile Retrieval Applied to the Observation Mode of the Michelson Interferometer for Passive Atmospheric Sounding, Appl. Optics, 40, 3559 3571, 2000.

Stiller, G. P. (Ed.) with contributions from v. Clarmann, T., Dudhia, A., Echle, G., Funke, B., Glatthor, N., Hase, F., Höpfner, M., Kellmann, S., Kemnitzer, H., Kuntz, M., Linden, A., Linder, M., Stiller, G. P., and Zorn, S.: The Karlsruhe Optimized and Precise Radiative Transfer Algorithm (KOPRA), vol. FZKA 6487 of Wissenschaftliche Berichte, Forschungszentrum Karlsruhe, Germany, 2000.

Stiller, G. P., von Clarmann, T., Funke, B., Glatthor, N., Hase, F., Höpfner, M., and Linden, A.: Sensitivity of trace gas abundances retrievals from infrared limb emission spectra to simplifying approximations in radiative transfer modelling, J. Quant. Spectrosc. Radiat. Transf., 72, 249-280, doi:10.1016/S00224073(01)00123-6, 2002.

Tikhonov, A.: On the solution of incorrectly stated problems and a method of regularization, Dokl. Acad. Nauk SSSR, 151, 501504, 1963.

Turquety, S., Hadji-Lazaro, J., Clerbaux, C., Hauglustaine, D. A., Clough, S. A., Cassé, V., Schlüssel, P. and Mégie, G., Operational trace gas retrieval algorithm for the Infrared Atmospheric Sounding Interferometer, J. Geophys. Res., 109, D21301, doi:10.1029/2004JD004821, 2004.

USEPA: Air Quality Criteria for Ozone and Other Photochemical Oxidants, Vol. II. EPA-600/P-93/00bF, US Environmental Protection Agency, National Center for Environmental Assessment, US Environmental Protection Agency, National Center for Environmental Assessment, Research Triangle Park, NC, USA, 1996.

Van Dingenen, R., Dentener, F. J., Raes, F., Krol, M. C., Emberson, L., and Cofala, J.: The global impact of ozone on agricultural crop yields under current and future air quality legislation, Atmos. Environ., 43, 604-618, 2009.

Worden, H. M., Logan, J. A., Worden, J. R., Beer, R., Bowman, K., Clough, S. A., Eldering, A., Fisher, B. M., Gunson, M. R., Herman, R. L., Kulawik, S. S., Lampel, M. C., Luo, M., Magretskaia, I. A., Osterman, G. B., and Shephard, M. W.: Comparisons of Tropospheric Emission Spectrometer (TES) ozone profiles to ozonesondes: Methods and initial results, Journal of Geophysical Research, 112, D03309, doi:10.1029/2006JD007258, 2007a.

Worden, J., Liu, X., Bowman, K., Chance, K., Beer, R., Eldering, A., Gunson, M., and Worden, H.: Improved tropospheric ozone profile retrievals using OMI and TES radiances, Geophys. Res. Lett., 34, L01809, doi:10.1029/2006GL027806, 2007b.

World Health Organization (WHO): Health Aspects of Air Pollution with Particulate Matter, Ozone and Nitrogen Dioxide, Bonn, Germany, 13-15 January 2003.

Zyryanov, D., Foret, G., Eremenko, M., Beekmann, M., Cammas, J.-P., D'Isidoro, M., Elbern, H., Flemming, J., Friese, E., Kioutsioutkis, I., Maurizi, A., Melas, D., Meleux, F., Menut, L., Moinat, P., Peuch, V.-H., Poupkou, A., Razinger, M., Schultz, M., Stein, O., Suttie, A. M., Valdebenito, A., Zerefos, C., Dufour, G., Bergametti, G., and Flaud, J.-M.: 3-D evaluation of tropospheric ozone simulations by an ensemble of regional Chemistry Transport Model, Atmos. Chem. Phys., 12, 3219-3240, doi:10.5194/acp-12-3219-2012, 2012. 